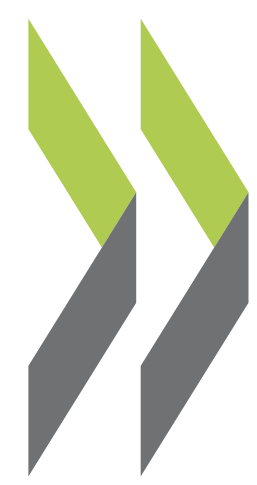

OECD Economics Department Working Papers No. 1023

Labour Market and Social Policies to Foster More Inclusive Growth in Sweden
Stéphanie Jamet,

Thomas Chalaux,

Vincent Koen 
Organisation de Coopération et de Développement Économiques

Organisation for Economic Co-operation and Development

18-Feb-2013

ECONOMICS DEPARTMENT

English - Or. English

\begin{abstract}
LABOUR MARKET AND SOCIAL POLICIES TO FOSTER
MORE INCLUSIVE GROWTH IN SWEDEN
\end{abstract}

ECONOMICS DEPARTMENT WORKING PAPERS No. 1023

By Stéphanie Jamet, Thomas Chalaux and Vincent Koen

All Economics Department Working Papers are available through OECD's Internet website at http://www.oecd.org/eco/workingpapers

JT03334800

Complete document available on OLIS in its original format

This document and any map included herein are without prejudice to the status of or sovereignty over any territory, to the delimitation of international frontiers and boundaries and to the name of any territory, city or area. 


\section{ABSTRACT/RÉSUMÉ \\ Labour market and social policies to foster more inclusive growth in Sweden}

Sweden is a very egalitarian country but inequalities have risen and some groups are poorly integrated into the labour market. For growth to become more inclusive, the gap between the cost of labour and productivity for some groups needs to be reduced, transitions from education to work should be facilitated, incentives to take a job ought to be strengthened and the non-employed need to be protected against the risk of falling into unemployment or inactivity traps. This calls for lowering minimum wages relative to the average wage for groups at risk of becoming unemployed, improving vocational education and training, and extending the coverage of the unemployment insurance while strengthening obligations for the unemployed. To address labour market duality risks, the gap in job protection between temporary and permanent contracts needs to be reduced. Women's employment is high but the gender wage gap could be narrowed further by enhancing their employment opportunities.

This Working Paper relates to the 2012 OECD Economic Survey of Sweden (www.oecd.org/eco/surveys/sweden).

JEL Classification: I3, I14, I28, J08, J3, J16, J51, J65.

Keywords: Sweden; inclusive growth; inequality; employment protection legislation; labour market dualism; minimum wage; labour costs; unemployment insurance; public employment service; vocational education and training; gender equality.

\section{$* * * * * * * * * * * * * * * * * * * *$ \\ Des politiques sociales et du marché du travail au service d'une croissance plus solidaire en Suède}

Bien qu'elle soit un pays très égalitaire, la Suède accuse aujourd'hui un creusement des inégalités, et certaines catégories de sa population restent en marge du marché du travail. Pour favoriser une croissance plus solidaire, il est nécessaire de réduire l'écart entre le coût du travail et la productivité de certaines catégories de main-d'œuvre, de faciliter le passage de l'école à la vie professionnelle, de renforcer les incitations au travail et de protéger les sans-emploi contre le piège du chômage ou de l'inactivité. Pour y parvenir, il faudra abaisser les minima salariaux par rapport au salaire moyen pour les groupes risquant de se retrouver au chômage, améliorer l'enseignement et la formation professionnelle et élargir la couverture de l'assurance-chômage, tout en renforçant les obligations des chômeurs. Pour faire face au risque de dualisme du marché du travail, les disparités dans la protection de l'emploi entre contrats temporaires et contrats permanents devront être réduites. Le taux d'emploi des femmes est certes élevé, mais l'écart salarial par rapport aux hommes pourrait être encore réduit en améliorant les perspectives d'emploi des femmes.

Ce Document de travail se rapporte à l'Étude économique de l'OCDE de la Suède, 2012 (www.oecd.org/eco/surveys/suède).

Classification JEL : I3, I14, I28, J08, J3, J16, J51, J65.

Mots clés : Suède, croissance inclusive, inégalités, législation pour la protection de l'emploi, dualisme du marché du travail, salaire minimum, coût du travail, assurance chômage, service public de l'emploi, apprentissage et formation professionnelle, égalité des genres.

(C) OECD (2013)

You can copy, download or print OECD content for your own use, and you can include excerpts from OECD publications, databases and multimedia products in your own documents, presentations, blogs, websites and teaching materials, provided that suitable acknowledgment of OECD as source and copyright owner is given. All requests for commercial use and translation rights should be submitted to rights@oecd.org 


\section{TABLE OF CONTENTS}

\section{LABOUR MARKET AND SOCIAL POLICIES TO FOSTER MORE INCLUSIVE GROWTH IN SWEDEN}

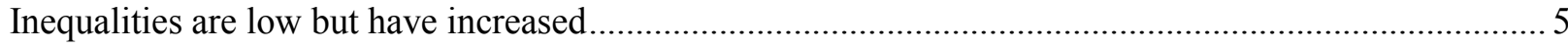

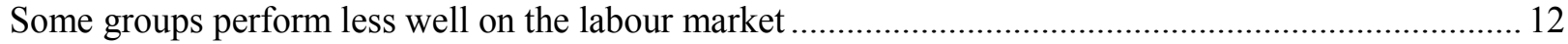

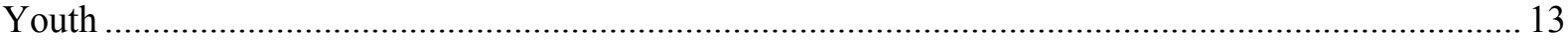

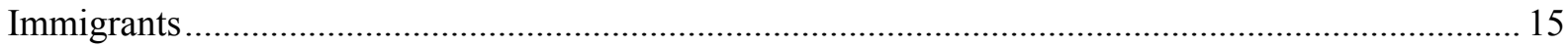

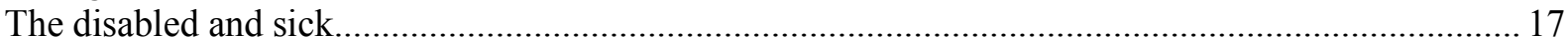

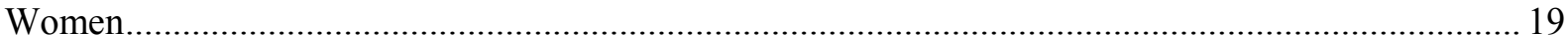

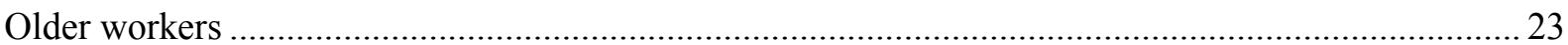

The earned-income tax credit provides stronger incentives to participate in the labour market............... 23

Entry thresholds in the labour market are high for some groups of workers ........................................... 25

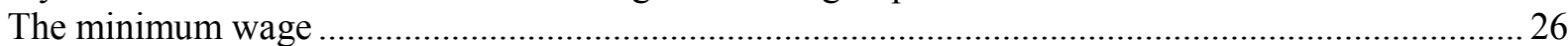

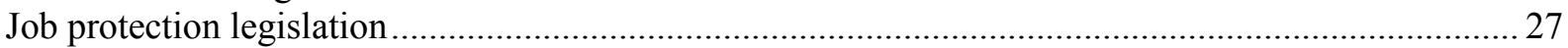

Support to the unemployed provides uneven social protection and incentives to take a job .................. 32

Job-search monitoring and the efficiency of ALMPs can be strengthened further .................................. 35

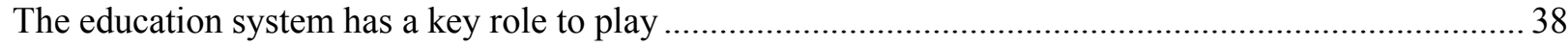

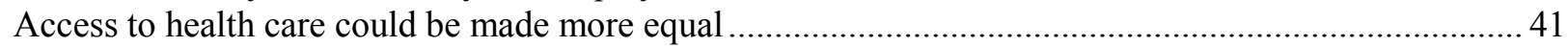

Women's employment opportunities could be improved further.......................................................... 42

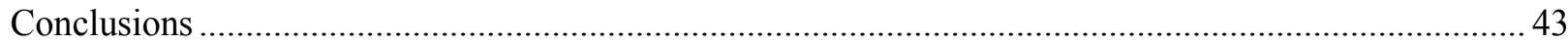

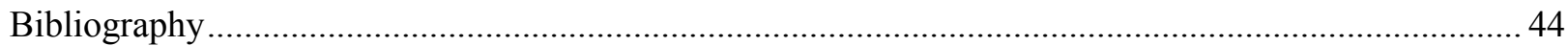

ANNEX 1 LABOUR MARKET AND EDUCATION MEASURES RECENTLY PROPOSED BY THE

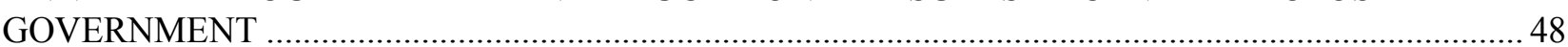

\section{Tables}

1. Average annual real disposable income growth per decile and country...................................... 9

2. Contributions of various income components to income growth per decile .............................. 10

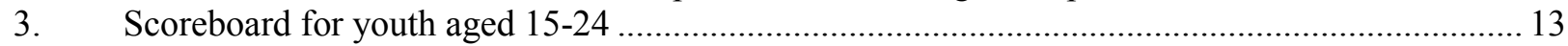

4. Characteristics of permanent residents by migration channel ................................................... 17

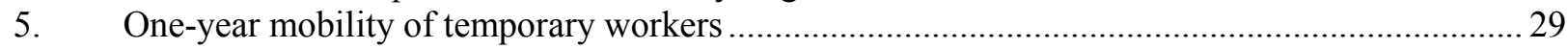

6. Explaining the transitions from temporary to permanent jobs or to unemployment ..................... 31

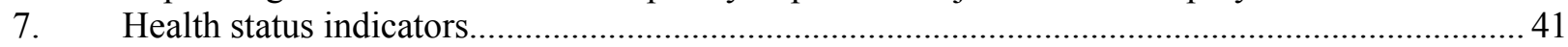

\section{Figures}

1. Inequality and relative poverty indicators in OECD countries.................................................. 6

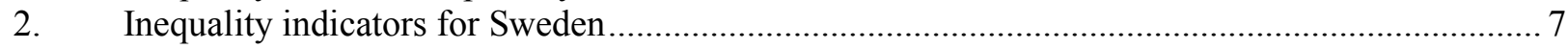

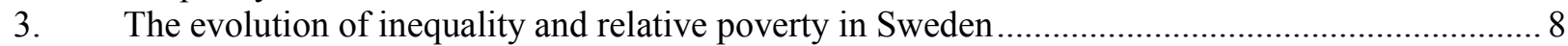

4. The impact of taxes and transfers on income inequalities .......................................................... 10

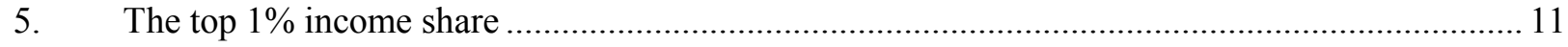

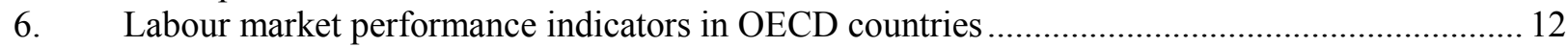

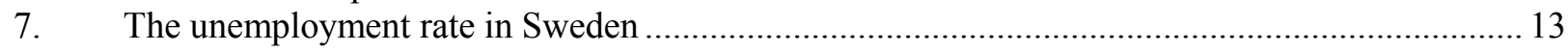


8. Estimated size of the group at risk: left behind and poorly integrated after a temporary job........ 14

9. Permanent immigration flows by category of entry ............................................................. 15

10. Gaps in labour market performance between natives and foreign-born in OECD countries ........ 16

11. Employment rates of people with disability and mental health problems ................................. 18

12. Evolution of the stock of recipients of sickness and disability benefits ...................................... 19

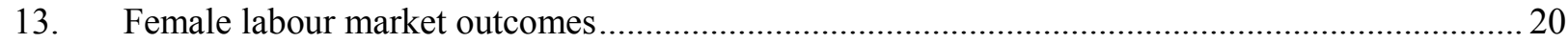

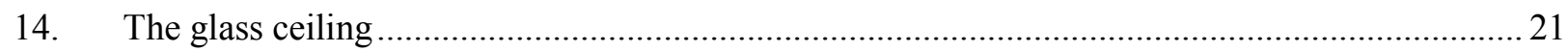

15. Main determinants of the gender pay gap in OECD countries ................................................. 22

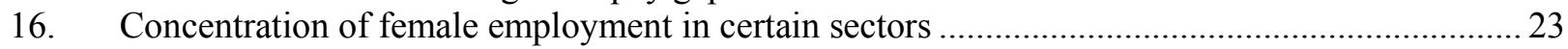

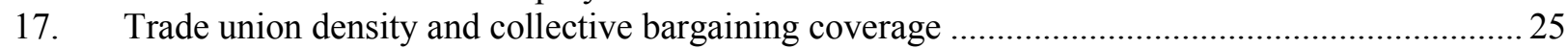

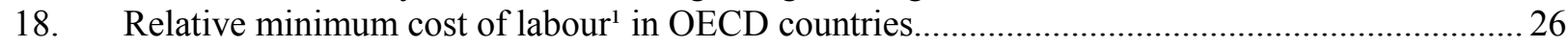

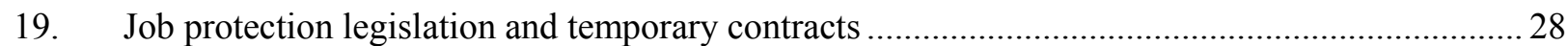

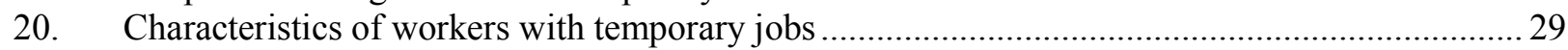

21. Characteristics influencing the mobility of temporary workers to permanent jobs...................... 30

22. Unemployed receiving unemployment insurance benefits ........................................................ 32

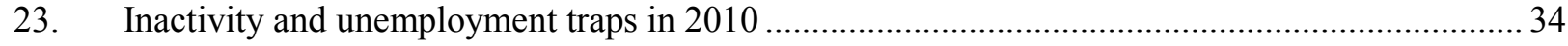

24. Public expenditure on active labour market policies in OECD countries ................................... 36

25. Overall strictness of eligibility criteria for unemployment benefit .............................................. 37

26. Gap in learning outcomes at age 15 between natives and foreign-born ...................................... 39

\section{Boxes}

Box 1. Inequalities in Sweden along various dimensions ................................................................. 7

Box 2. Measuring the share of youth at risk of being left behind and poorly integrated ........................ 14

Box 3. Explaining the mobility of temporary workers in EU countries and in Sweden ........................... 31

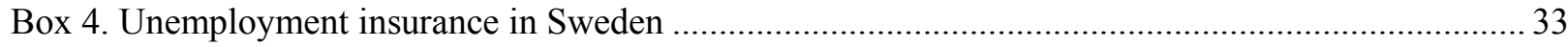

Box 5. Targeting youth risking long-lasting social exclusion ........................................................... 35

Box 6. Improving vocational education and training in Sweden ....................................................... 40

Box 7. Key labour market and social policy recommendations to make growth more inclusive ............. 43

The statistical data for Israel are supplied by and under the responsibility of the relevant Israeli authorities. The use of such data by the OECD is without prejudice to the status of the Golan Heights, East Jerusalem and Israeli settlements in the West Bank under the terms of international law. 
ECO/WKP(2013)15

\title{
LABOUR MARKET AND SOCIAL POLICIES TO FOSTER MORE INCLUSIVE GROWTH IN SWEDEN
}

\author{
Stéphanie Jamet, Thomas Chalaux and Vincent Koen ${ }^{1}$
}

\section{Inequalities are low but have increased}

Sweden stands out among OECD members as a country with a low level of inequalities. This holds for income distribution as captured by the Gini coefficient (Figure 1). It also holds for poverty: relative poverty is well below the OECD average and material deprivation is low (Nolan and Whelan, 2010). The OECD has recently mapped inequalities across a large number of dimensions and virtually all indicators point in the same direction (Box 1).

However, inequalities have been rising since the early 1990s (Figure 3). While this has been true in most OECD countries, the increase in Sweden has been among the steepest (OECD, 2011a). As in most countries, household incomes increased faster at the top of the distribution, but the contrast was particularly stark in Sweden (Table 1). Furthermore, while in many EU countries, income growth has been fairly uniform across deciles between the second and the ninth, in Sweden, growth has been faster the higher the income decile, pointing to some polarisation of the income distribution (Figure 3, Panel B). Relative poverty has increased with those without a job and children now facing a higher risk of poverty (Figure 3, Panel C).

1. The authors work in the Economics Department of the OECD. This paper was originally produced for the 2012 OECD Economic Survey of Sweden published in December 2012 under the authority of the Economic and Development Review Committee (EDRC) of the OECD. The authors would like to thank Müge Adalet McGowan, Olof Åslund, Andrew Dean, Jørgen Elmeskov, Robert Ford, Anders Forslund, Michael Förster, Thomas Liebig, Shruti Singh, Anne Sonnet, Danielle Venn, as well as officials from the Swedish government, for valuable discussions and comments on earlier drafts. Special thanks go to Nadine Dufour and Pascal Halim for technical preparation. 
Figure 1. Inequality and relative poverty indicators in OECD countries
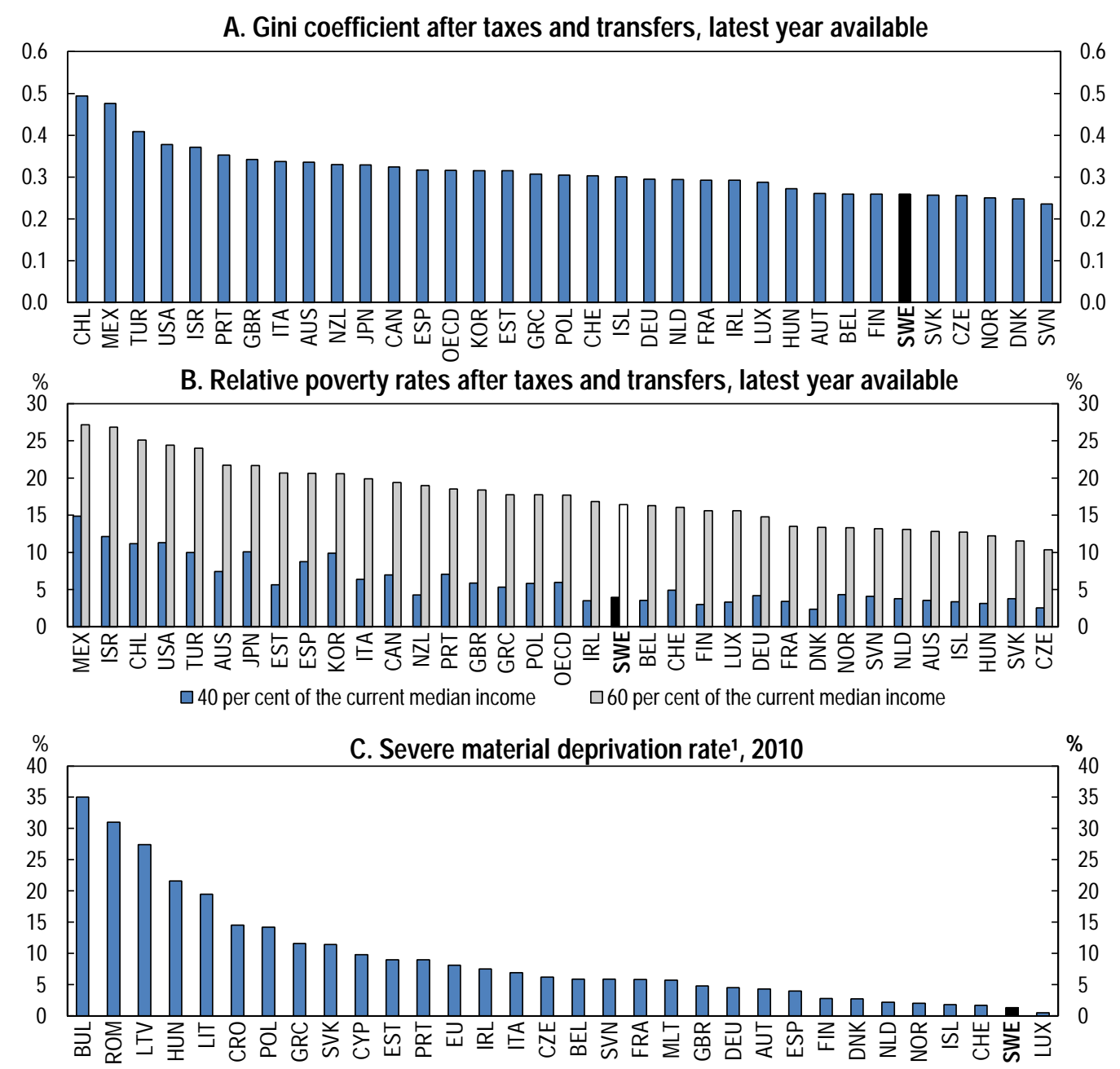

Note: Panels A and B are based on equivalised household disposable income, after taxes and transfers, entire population.

1. Severe material deprivation is defined as the inability to afford at least four of the following items: (1) to pay their rent, mortgage or utility bills; (2) to keep their home adequately warm; (3) to face unexpected expenses; (4) to eat meat or proteins regularly; (5) to go on holiday; (6) a television set; (7) a washing machine; (8) a car; (9) a telephone.

Source: A and B: OECD, Income Distribution and Poverty Database. C: Eurostat. 


\section{Box 1. Inequalities in Sweden along various dimensions}

For Sweden, the indicator set developed in Hoeller et al. (2012) reveals that inequality in household disposable income, whether adjusted or not for in-kind public services, is low in international comparison (Figure 2). Inequality in individual labour earnings for the working age population is low, reflecting both a narrow wage dispersion and a nonemployment rate below the OECD average. Capital income is slightly more concentrated than in the OECD on average but overall the Gini index of household market income for the entire population remains well below the OECD average. Taxes and cash transfers bring inequality in household disposable income significantly below the OECD average, and in-kind transfers work in the same direction. Health and education services tend to have a slightly less redistributive impact than on average in the OECD mainly because of their universal nature in Sweden. However, other services, such as child care, public transport and social housing are more redistributive than in other countries and on the whole, the inequality indicator adjusted for in-kind public spending is the lowest among all OECD countries (OECD, 2011a).

Figure 2. Inequality indicators for Sweden

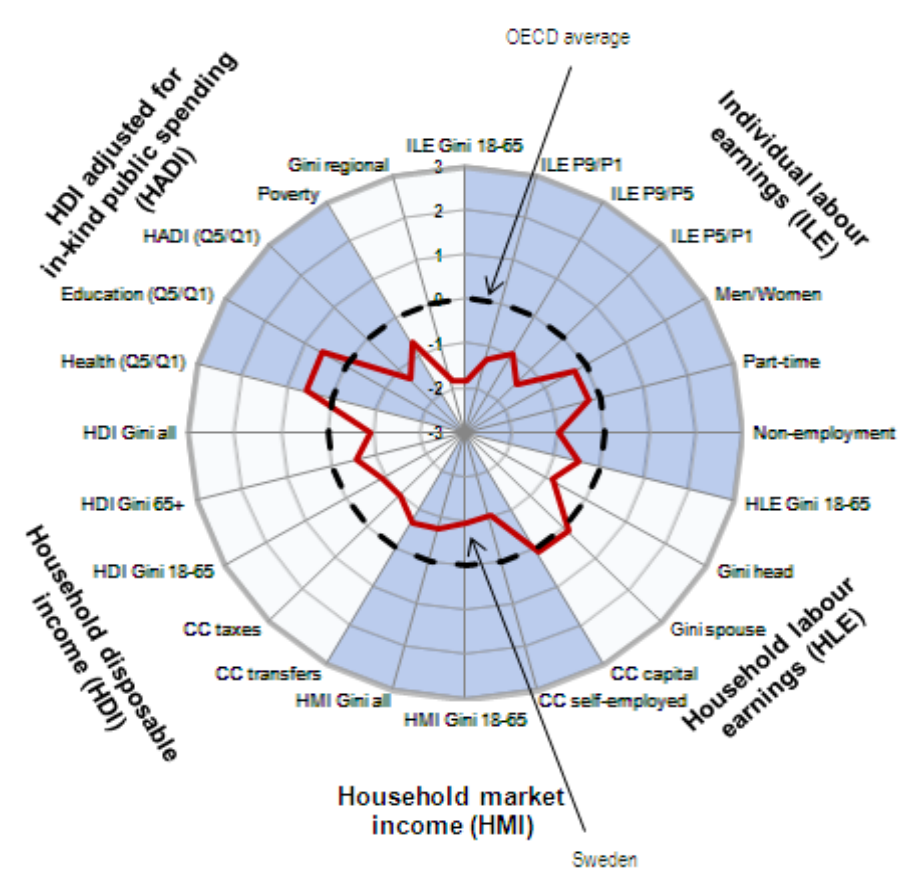

Note: Data refer to 2008 for Sweden and to the late 2000s for the OECD average. The dotted line represents the OECD average and the solid line Sweden. Where the solid line falls inside the OECD average, this implies less inequality than the OECD average, and vice versa. The indicators are presented in units of standard deviation.

ILE: ILE Gini 18-65 = for working age population, including wage earners, self-employed, unemployed and non-employed; ILE P9/P1 $=$ ninth to first decile, wage earnings for full-time employees; ILE P9/P5 = ninth to fifth decile, wage earnings for full-time employees; ILE P5/P1 = fifth to first decile, wage earnings for full-time employees. Men/Women = median wage earnings of men to women. Parttime $=$ ratio of part-time workers to total employment. Non-employment rate $=$ as a share of the working age population.

HLE: HLE Gini 18-65 = for working age population. Gini head = for heads of household. Gini spouse = for spouses.

HMI: CC capital $=$ concentration coefficient for capital income. CC self-employed $=$ concentration coefficient for self-employment income. HMI Gini 18-65 = for working age population, HMI Gini all = for total population.

HDI: CC transfers = concentration coefficient for cash transfers. CC taxes = Concentration coefficient for household taxes. HDI Gini $18-65$ = for working age population. HDI Gini $65+=$ for population aged 66 and over HDI. Gini all = for total population.

HADI: Health Q5/Q1 = public spending on health, fifth to first quintile; Education Q5/Q1 = public spending on education and early childhood education and care, fifth to first quintile; HADI Q5/Q1 = HDI adjusted for in-kind health and education public spending, fifth to first quintile.

Poverty $=$ relative poverty rate; Gini regional $=$ for regional GDP.

Source: Hoeller, P., I. Joumard, M. Pisu and D. Bloch (2012), "Less Income Inequality and More Growth - Are They Compatible? Part 1. Mapping Income Inequality Across the OECD”, OECD Economics Department Working Papers, No. 924. 
Figure 3. The evolution of inequality and relative poverty in Sweden
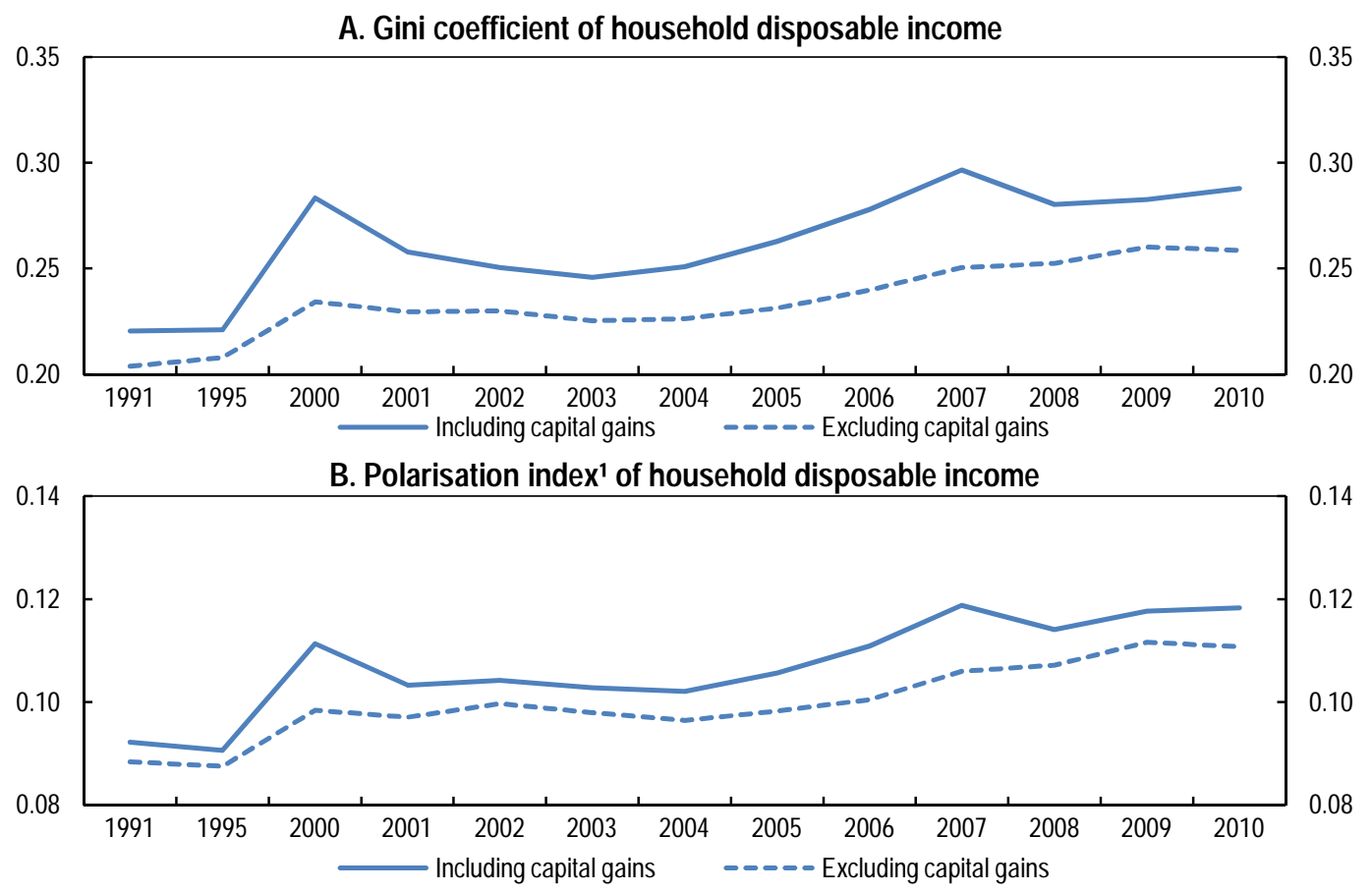

C. Contribution from subgroups to the relative income poverty rate at $50 \%$ of

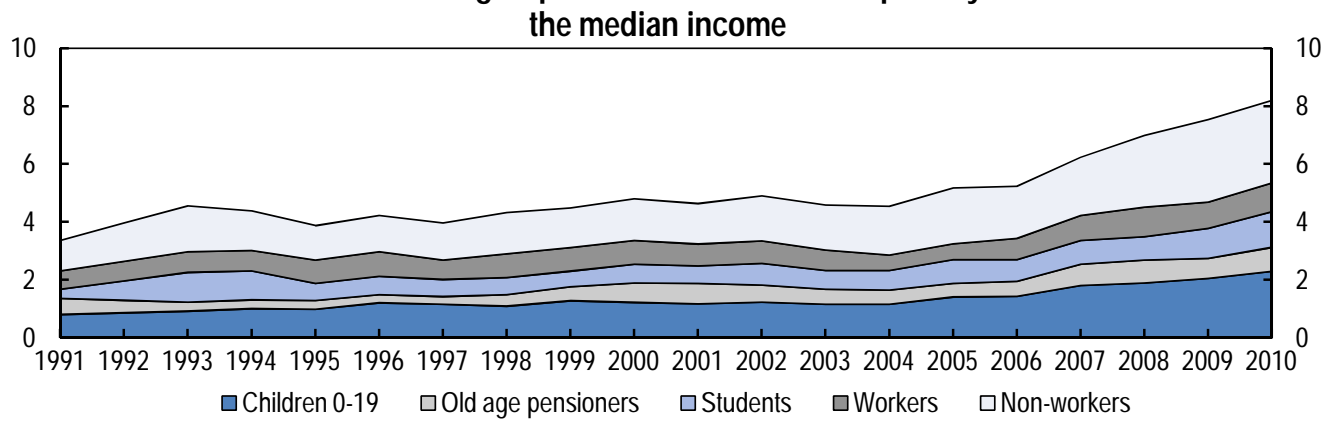

Note: Panels A and B are based on equivalised household disposable income, after taxes and transfers, entire population.

1. The Foster and Wolfson polarisation index measures the extent to which the distribution is spread out from the middle. More precisely it is the area delineated by the vertical distance between the Lorenz curve and the tangent to that curve at the median.

Source: OECD estimates; Statistics Sweden and Swedish Ministry of Finance. 
ECO/WKP(2013)15

Table 1. Average annual real disposable income growth per decile, by country ${ }^{1}$

Between the mid-1990s and 2008, percentage change

\begin{tabular}{|c|c|c|c|c|c|c|c|c|c|c|}
\hline Decile & 1 & 2 & 3 & 4 & 5 & 6 & 7 & 8 & 9 & 10 \\
\hline Denmark & 0.3 & 0.8 & 0.8 & 0.9 & 1.0 & 1.1 & 1.1 & 1.2 & 1.2 & 2.7 \\
\hline Finland & 1.4 & 1.4 & 1.7 & 2.1 & 2.3 & 2.4 & 2.5 & 2.5 & 2.6 & 4.8 \\
\hline France & 1.2 & 1.4 & 1.4 & 1.4 & 1.3 & 1.2 & 1.2 & 1.2 & 1.2 & 2.4 \\
\hline Germany & -0.1 & -0.2 & 0.0 & 0.0 & 0.2 & 0.2 & 0.2 & 0.3 & 0.4 & 1.3 \\
\hline Greece & 6.1 & 4.7 & 4.4 & 4.0 & 3.7 & 3.5 & 3.4 & 3.3 & 3.3 & 3.0 \\
\hline Italy & 2.6 & 1.6 & 1.1 & 1.1 & 0.9 & 0.9 & 0.8 & 0.8 & 0.9 & 0.9 \\
\hline Luxemburg & 1.3 & 1.7 & 1.9 & 2.0 & 2.2 & 2.3 & 2.3 & 2.2 & 2.4 & 3.7 \\
\hline Netherlands & -0.3 & 0.4 & 0.5 & 0.4 & 0.4 & 0.3 & 0.3 & 0.4 & 0.6 & 2.4 \\
\hline Sweden & 0.7 & 1.2 & 1.8 & 2.2 & 2.4 & 2.6 & 2.7 & 2.8 & 2.9 & 3.5 \\
\hline United Kingdom & 0.5 & 2.6 & 2.6 & 2.5 & 2.4 & 2.4 & 2.5 & 2.5 & 2.6 & 4.0 \\
\hline Weighted EU average ${ }^{1}$ & 1.2 & 1.4 & 1.4 & 1.4 & 1.3 & 1.3 & 1.3 & 1.3 & 1.4 & 2.3 \\
\hline United States & -0.4 & 0.5 & 0.5 & 0.5 & 0.6 & 0.7 & 0.8 & 0.9 & 0.9 & 1.2 \\
\hline
\end{tabular}

1. Average household income per decile deflated by the consumer price index. Entire population. EU average weighted with population size.

Source: Bonesmo Fredriksen, K. (2012), "Income Inequality in the European Union”, OECD Economics Department Working Papers, No. 952; OECD, Income Distribution and Poverty Database.

The cross-country literature on the drivers of household income inequalities shows that changes in the distribution of wages and salaries play a major role (Kierzenkowski and Koske, 2012). Changes in the structure of households due to factors such as population ageing and the trend towards smaller household sizes have also been important in several countries. In Sweden for instance, $25 \%$ of the increase in household earnings inequalities over 1991-2005 came from changes in the household structure (OECD, 2011a). Finally, in half of the OECD countries, income taxes and cash transfers have become less effective in reducing market income inequalities during the late 1990s and early 2000s. The underlying causes of the recent changes in inequality remain subject to debate. Globalisation and technological change are the leading contenders (OECD, 2011a). Structural reforms also affect inequality but their impact depends on the type of reform (Fournier and Koske, 2012).

In Sweden, the decomposition of household disposable income by component shows that across much of the distribution, income growth over 1995-2010 has mainly been driven by labour income, with wage growth weak for the three bottom deciles and stronger for the upper ones (Table 2). Social transfers and taxes have redistributed income from the upper deciles to the bottom ones, but their equalising role has become less pronounced (Figure 4). Over 2000-10, wage growth has been modest for the first three deciles but also for the top decile. The relatively weak growth of wages for the top decile likely reflects a substitution from labour to capital that has been encouraged by the tax system (OECD, 2012a). Changes in transfers have positively contributed to income growth for the lowest deciles while changes in taxes have mostly benefited to middle and upper deciles. 
Table 2. Contributions of various income components to income growth per decile ${ }^{1}$ Sweden, contribution to average annual percentage change

$1995-2010$

\begin{tabular}{|c|c|c|c|c|c|c|c|c|c|c|}
\hline Decile & 1 & 2 & 3 & 4 & 5 & 6 & 7 & 8 & 9 & 10 \\
\hline Wage of the household head & -0.1 & 0.1 & 0.9 & 1.6 & 1.9 & 1.9 & 2.2 & 2.2 & 2.0 & 2.4 \\
\hline Wage of the household & & & & & & & & & & \\
\hline spouse and other members & -0.1 & 0.0 & 0.3 & 0.5 & 0.6 & 1.0 & 1.3 & 1.4 & 1.5 & 1.5 \\
\hline Capital income & -0.1 & 0.1 & 0.3 & 0.3 & 0.2 & 0.2 & 0.1 & 0.2 & 0.3 & 1.4 \\
\hline Self-employment income & -0.2 & 0.0 & 0.0 & 0.1 & 0.2 & 0.2 & 0.2 & 0.2 & 0.3 & 0.4 \\
\hline Social security transfers & 0.9 & 1.3 & 0.8 & 0.2 & 0.1 & -0.1 & -0.2 & -0.2 & -0.3 & 0.0 \\
\hline Direct taxes and social & & & & & & & & & & \\
\hline security contributions & 0.3 & -0.1 & -0.2 & -0.2 & -0.1 & -0.2 & -0.2 & -0.3 & -0.3 & -1.1 \\
\hline Other & 0.0 & -0.1 & -0.2 & -0.4 & -0.5 & -0.5 & -0.6 & -0.6 & -0.7 & -1.0 \\
\hline \multirow[t]{3}{*}{ Total income growth } & 0.8 & 1.3 & 1.7 & 2.1 & 2.4 & 2.6 & 2.7 & 2.8 & 2.9 & 3.6 \\
\hline & \multicolumn{10}{|c|}{$2000-10$} \\
\hline & 1 & 2 & 3 & 4 & 5 & 6 & 7 & 8 & 9 & 10 \\
\hline Wage of the household head & -0.1 & -0.1 & 0.3 & 0.9 & 1.2 & 1.2 & 1.4 & 1.3 & 1.1 & 0.3 \\
\hline $\begin{array}{l}\text { Wage of the household } \\
\text { spouse and other members }\end{array}$ & 0.0 & 0.0 & 0.1 & 0.2 & 0.2 & 0.4 & 0.7 & 0.7 & 0.7 & 1.0 \\
\hline Capital income & -0.2 & 0.0 & 0.4 & 0.4 & 0.2 & 0.3 & 0.1 & 0.2 & 0.3 & 1.0 \\
\hline Self-employment income & -0.1 & -0.1 & -0.1 & 0.0 & 0.0 & 0.1 & 0.1 & 0.1 & 0.2 & 0.2 \\
\hline Social security transfers & 0.7 & 1.1 & 0.6 & 0.3 & 0.2 & 0.1 & -0.1 & 0.1 & 0.0 & 0.1 \\
\hline $\begin{array}{l}\text { Direct taxes and social } \\
\text { security contributions }\end{array}$ & 0.4 & 0.3 & 0.4 & 0.5 & 0.7 & 0.7 & 0.7 & 0.6 & 0.7 & 0.6 \\
\hline Other & 0.0 & -0.1 & -0.1 & -0.2 & -0.3 & -0.3 & -0.3 & -0.3 & -0.3 & -0.4 \\
\hline Total income growth & 0.6 & 1.2 & 1.6 & 2.1 & 2.4 & 2.5 & 2.6 & 2.6 & 2.6 & 2.8 \\
\hline
\end{tabular}

1. Average household income per decile deflated by the consumer price index. Entire population, excluding capital gains.

Source: OECD, Income Distribution and Poverty Database; Swedish Ministry of Finance; OECD calculations.

Figure 4. The impact of taxes and transfers on income inequalities

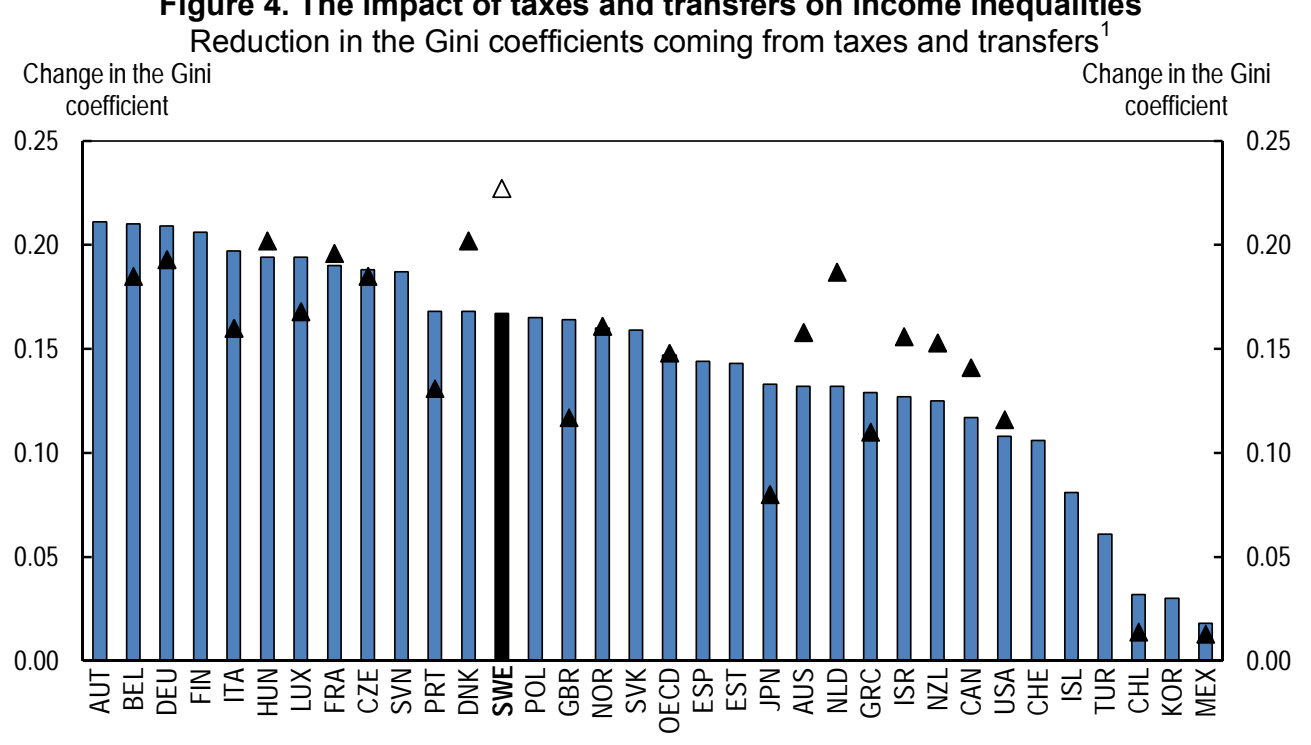

$\square$ late-2000s $\Delta$ mid-90s

1. The redistributive impact of taxes and transfers is defined as the difference in the Gini coefficients for income before cash transfers and taxes (i.e. household market income) and after cash transfers and taxes (i.e. household disposable income). For instance in Sweden, the Gini coefficient was reduced through taxes and transfers from 0.44 to 0.21 (hence by 0.23 ) in the mid1990 s and from 0.43 to 0.26 (hence by 0.17 ) in the late 2000 s. Entire population.

Source: OECD, Income Distribution and Poverty Database. 
Capital income has largely driven the rise in inequalities since the early 1990s as it went increasingly to richer households even if the share of capital income in total income remained stable (OECD, 2011a). In addition, capital gains have contributed to the increase in inequalities. When this source of income is excluded, the increase in inequalities since the early 1990s is smaller (Figure 3). The top decile, and more precisely the top percentile, has mainly benefited from this source of revenues, especially in recent years, at least partly reflecting high compensation for chief executives and other high-income individuals (Waldenström, 2009; Björklund et al., 2012). When capital gains are included, Sweden exhibits a sharp increase in the pre-tax income share of the top percentile, although less marked than in the United States (Figure 5).

Figure 5. The top $1 \%$ income share

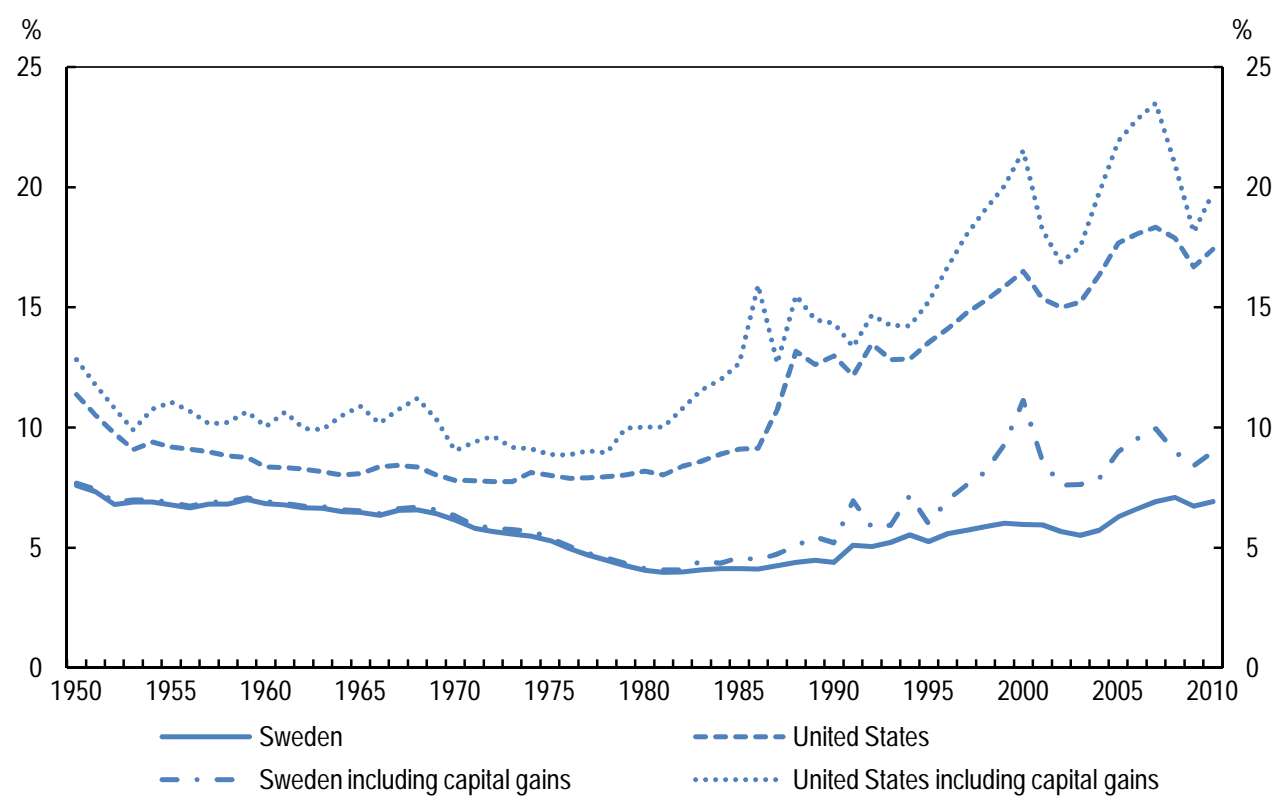

Source: The World Top Incomes Database, http://g-mond.parisschoolofeconomics.eu/topincomes.

Whether this rise in inequality was unavoidable for Sweden to achieve an average rate of growth of $3 \%$ per annum over 1995-2008 is an open question. The cross-country empirical evidence on the links between inequality and growth has been inconclusive so far (De Dominicis et al., 2008). One the one hand, inequalities may push up growth insofar as work incentives are stronger in more unequal societies, as higher-income individuals save a higher share of their earnings, and as wealth concentration favours the creation of new activities when there are sunk costs to investment (Aghion et al., 1999). On the other hand, insofar as more unequal countries tend to redistribute more, this entails distortions that act as a drag on growth; large inequalities foster political and social instability which deters investment; and in the presence of credit market imperfections, inequality leads to under-investment in human capital. Another question is whether the increase in inequalities in Sweden should be a source of concern given that inequalities remain very low from an international perspective.

Sweden undertook many structural reforms to consolidate its public finances in the wake of the banking crisis of the early 1990s. They included reforms of the unemployment insurance and pension systems, and, more recently, a reform of the sickness and disability benefit system. The overall purpose of these reforms was to make the welfare and tax systems more conducive to labour market participation. It is therefore not surprising that inequalities increased after the mid-1990s, especially because positive effects on employment take time to materialise and the share of less productive workers may have increased. 


\section{Some groups perform less well on the labour market}

Good labour market outcomes are key to containing the rise in inequalities. Sweden performs very well in terms of most labour market indicators (Figure 6). Structural reforms have helped to raise employment rates to high levels and to lower the unemployment rate, although it never returned to its pre-1990s crisis level, partly because participation rates have also increased (Figure 7). However, groups who are given incentives to join the labour force but fail to find a job risk becoming long-term unemployed and discouraged. This in turn raises demands for inactivity benefits, which can undermine the success of

Figure 6. Labour market performance indicators in OECD countries 2011
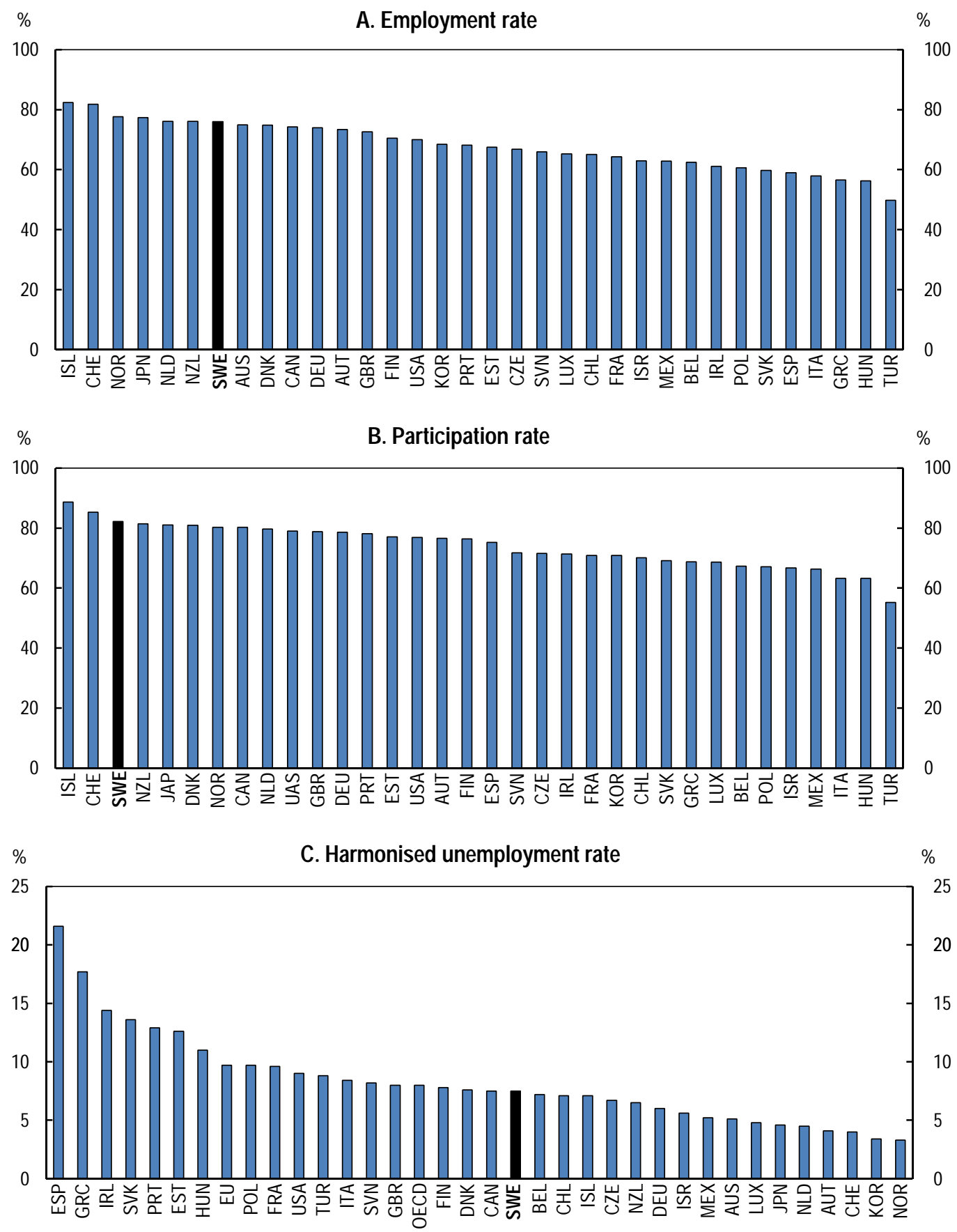

Source: OECD, Labour Force Statistics. 
Sweden's structural reforms agenda. Furthermore, higher risks of exclusion for some groups can worsen inequalities in opportunities, in a context where geographical segregation and the evolution of the structure of couples (with both members more often having a similar socio-economic background) make children more likely to inherit their parents' labour market situation.

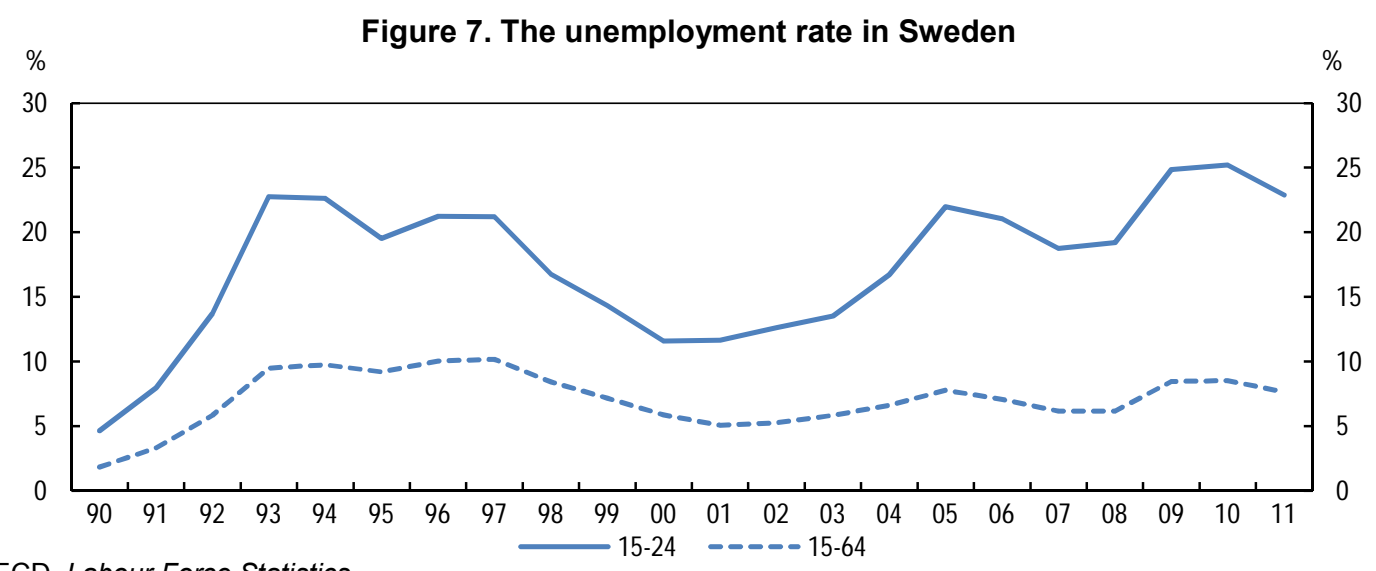

Source: OECD, Labour Force Statistics.

\section{Youth}

Youth with a low level of education are one of the main groups at risk. They are more likely to be non-employed or to go back and forth between temporary employment and inactivity (OECD, 2010a). Youth have less access to welfare benefits (see below) and are therefore potentially more exposed to the risk of poverty. Overall, the situation is better in Sweden than in many other OECD countries (Table 3).

Table 3. Scoreboard for youth aged 15-24

\begin{tabular}{|c|c|c|c|c|c|c|}
\hline & \multicolumn{3}{|c|}{2001} & \multicolumn{3}{|c|}{2011} \\
\hline & Sweden & $E^{b}$ & OECD $^{b}$ & Sweden & $E^{b}$ & OECD $^{b}$ \\
\hline Employment rate (\% of the age group) & 48.7 & 40.2 & 43.3 & 40.4 & 33.4 & 37.8 \\
\hline Unemployment rate (UR) (\% of the labour force) & 11.6 & 16.5 & 14.5 & 22.9 & 22.8 & 19.0 \\
\hline $\begin{array}{l}\text { Difference in UR between youth }{ }^{\mathrm{a}} \text { and adult } \\
(15-24)-(25-54)\end{array}$ & 7.5 & 9.4 & 7.0 & 17.4 & 12.1 & 9.0 \\
\hline $\begin{array}{l}\text { Unemployment to population ratio } \\
\text { (\% of the age group) }\end{array}$ & 6.4 & 7.3 & 6.7 & 12.0 & 9.0 & 8.1 \\
\hline $\begin{array}{l}\text { Incidence of long-term unemployment } \\
\text { (\% of unemployment) }\end{array}$ & 7.0 & 25.4 & 18.7 & 5.4 & 28.0 & 22.1 \\
\hline Incidence of temporary work (\% of employment) & 47.8 & 33.1 & 30.0 & 57.5 & 40.6 & 38.2 \\
\hline Incidence of part-time work (\% of employment) & 32.7 & 16.8 & 20.6 & 36.6 & 25.4 & 27.9 \\
\hline NEET rate $^{c}$ (\% of the age group) & 7.4 & 13.6 & 13.2 & 10.8 & 11.2 & 12.8 \\
\hline School drop-outs ${ }^{d}(\%$ of the age group) & 8.2 & 19.9 & 22.7 & 7.4 & 15.1 & 19.6 \\
\hline $\begin{array}{l}\text { Difference in UR between low skills and high skills } \\
(\text { ISCED<3-ISCED>5) }\end{array}$ & n.a. & 10.1 & 8.8 & 19.6 & 14.3 & 11.5 \\
\hline
\end{tabular}

UR: unemployment rate; NEET: neither in education nor in employment or training; ISCED 3 and 5: International standard of education referring to, respectively, upper secondary education and first phase of tertiary education.

a) Youth aged 16-24 for Iceland, Spain, Sweden, the United Kingdom and the United States; youth aged 15-24 for all other countries; youth aged 20-24 for school drop-outs.

b) Unweighted average of the $21 \mathrm{EU}$ and 34 OECD countries.

c) 2000 and 2010 .

d) Share of youth not in education and without an ISCED 3 educational attainment; 1999 and 2009.

Source: OECD Project on Jobs for Youth (www.oecd.org/employment/youth) from OECD Employment Database and OECD, Education Database. 
The NEET rate - the share of youth who are neither employed, nor in education or training - is among the lowest among OECD countries (OECD, 2012b). The youth unemployment rate is high in Sweden but to some extent this reflects statistical issues (Box 2). Unemployment spells are very short for most young people: in $2011,68 \%$ of the unemployed aged 15 to 24 were in unemployment for less than three months. However, youth have been hit particularly hard by the crisis, with their unemployment rate rising more than for the working age population as a whole (Figure 7) and the NEET rate also increasing. Also, their likelihood of holding a temporary job has increased with the crisis.

\section{Box 2. Measuring the share of youth at risk of being left behind and poorly integrated}

The OECD Jobs for Youth review identified two groups of youth that face particular difficulties in getting a stable job after leaving school: the so-called "youth left behind" and "poorly-integrated new entrants" (Figure 8). The size of these two groups is, however, difficult to estimate.

The "youth left behind" include those who lack qualifications, those coming from an immigrant or minority background and/or those living in disadvantaged, rural or remote neighbourhoods. The size of this group is proxied by the number of young people aged 15-29 who are neither in employment, nor in education or training (NEET) and who lack an upper secondary education, which was around $10 \%$ in 2011.

The "poorly-integrated new entrants" include youth who often have diplomas but find it difficult to obtain stable employment, even during periods of strong economic growth. They frequently go back and forth between temporary jobs, unemployment or inactivity. The size of this group is proxied by the proportion of youth-out-of-school employed on a temporary basis in 2005 who were still in temporary employment, unemployed or inactive two years afterwards.

The youth unemployment rate can be a misleading indicator. Indeed, it depends on the country characteristics of youth labour force participation. In Sweden for instance, it is often argued that a large share of the young unemployed are full time students who mainly define themselves as students (Government Offices of Sweden, 2012). Indeed, in $2010,6.5 \%$ of the young aged 15 to 29 were in education and also unemployed - well above the $1.9 \%$ OECD average. By contrast, $5.5 \%$ of them were not in education and unemployed, against $6.7 \%$ on average in the OECD (OECD, $2012 b$ ). Therefore it is more informative to look at NEET indicators (Table 3 ).

Figure 8. Estimated size of the group at risk: left behind and poorly integrated after a temporary job' 2008

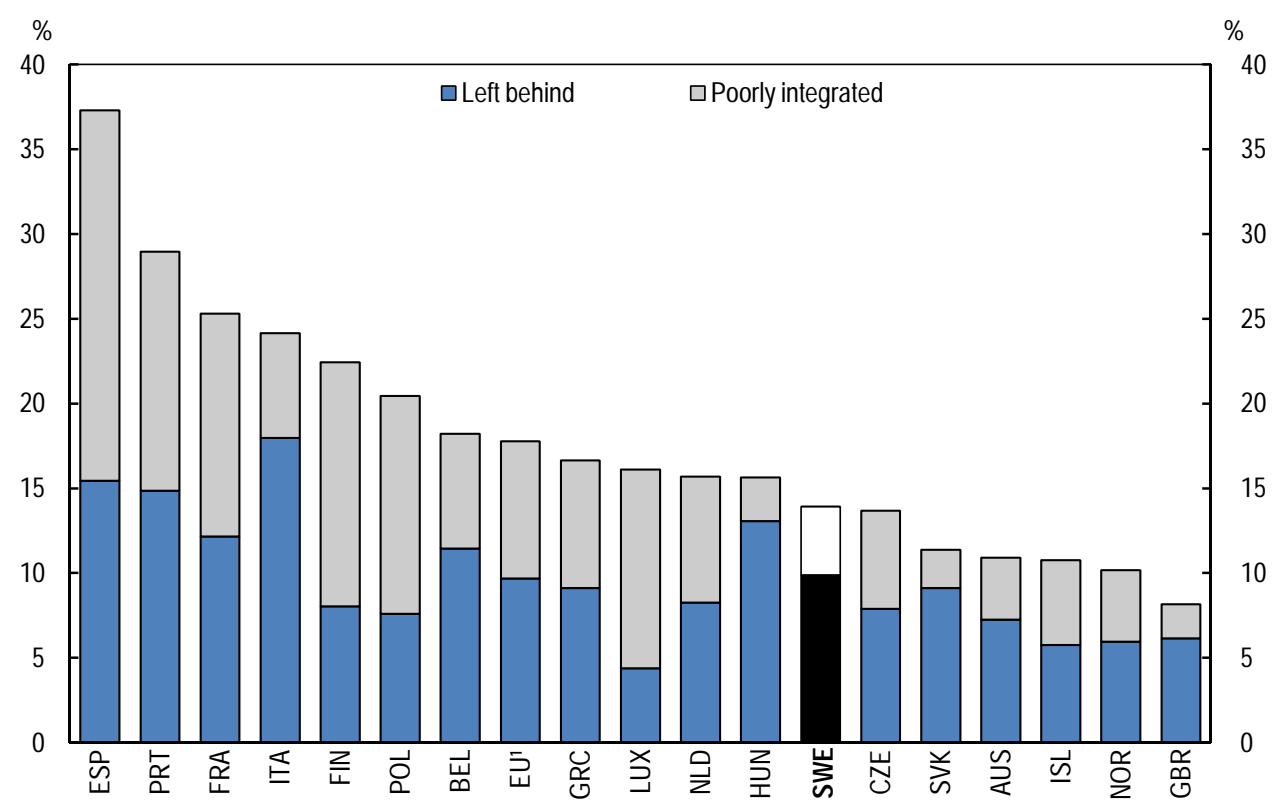

1. Estimates for youth aged $15-29$ as a percent of the youth aged 15-29 having left education.

Source: OECD (2010), Off to a Good Start? Jobs for Youth, Paris. 


\section{Immigrants}

Some immigrants also face a high risk of being excluded from the labour market and more generally from society. Compared with other OECD countries and relative to its population, migration to Sweden has been high over the past decade (Figure 9). Sweden has had limited success with the integration of these migrants. The gap in unemployment rates between the foreign-born and the natives is wide (Figure 10). Foreign-born women show a particularly weak attachment to the labour market as they are more often inactive than native women. The foreign-born have also lower income than the natives and, thus, are more exposed to poverty risk.

\section{Figure 9. Permanent immigration flows by category of entry}

Legal permanent type-immigrants, per thousand persons in the resident population, over 2002-10

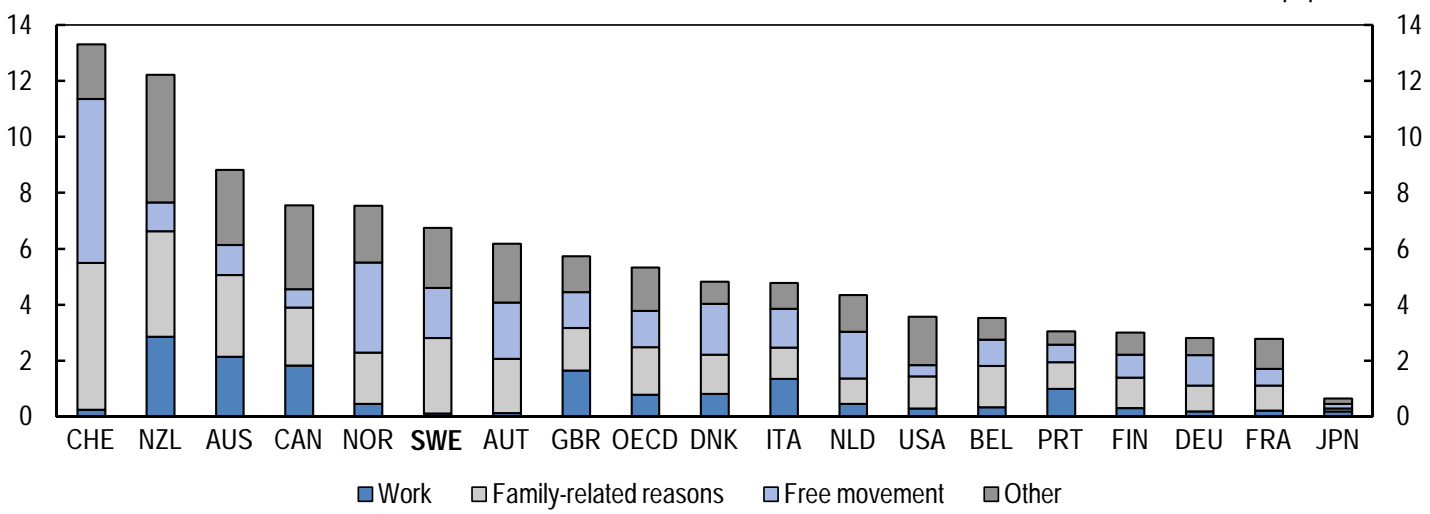

Source: OECD, International Migration Database. 
Figure 10. Gaps in labour market performance between natives and foreign-born in OECD countries

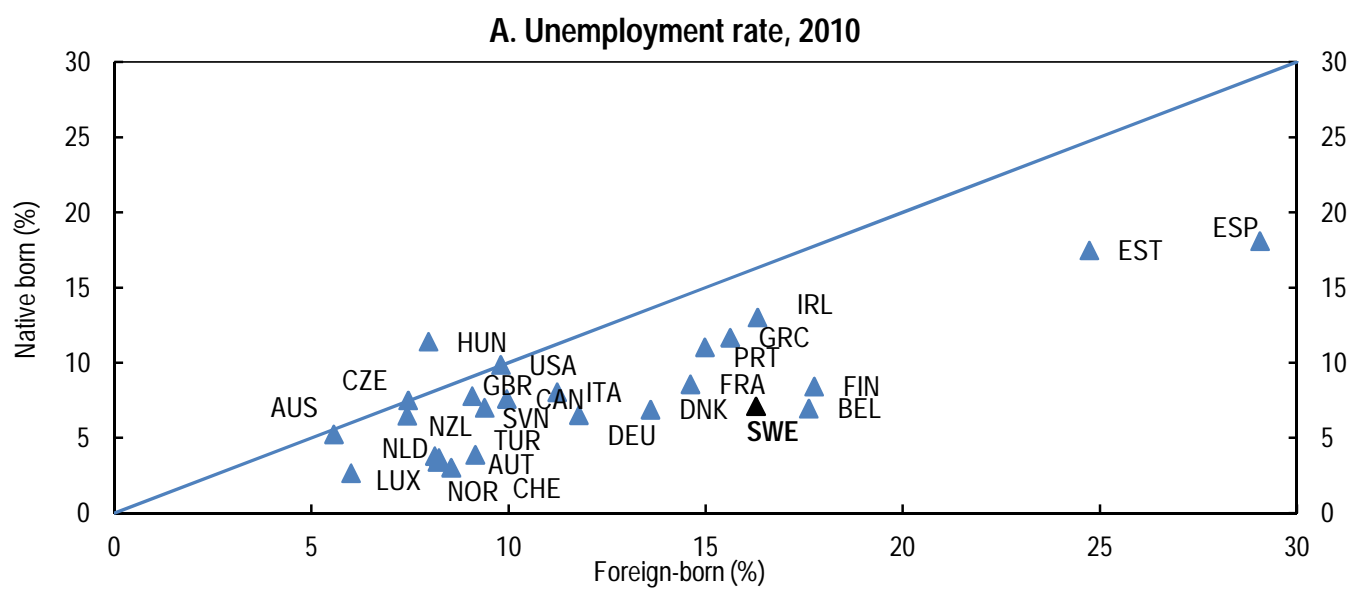

B. Employment rate of women, 2010
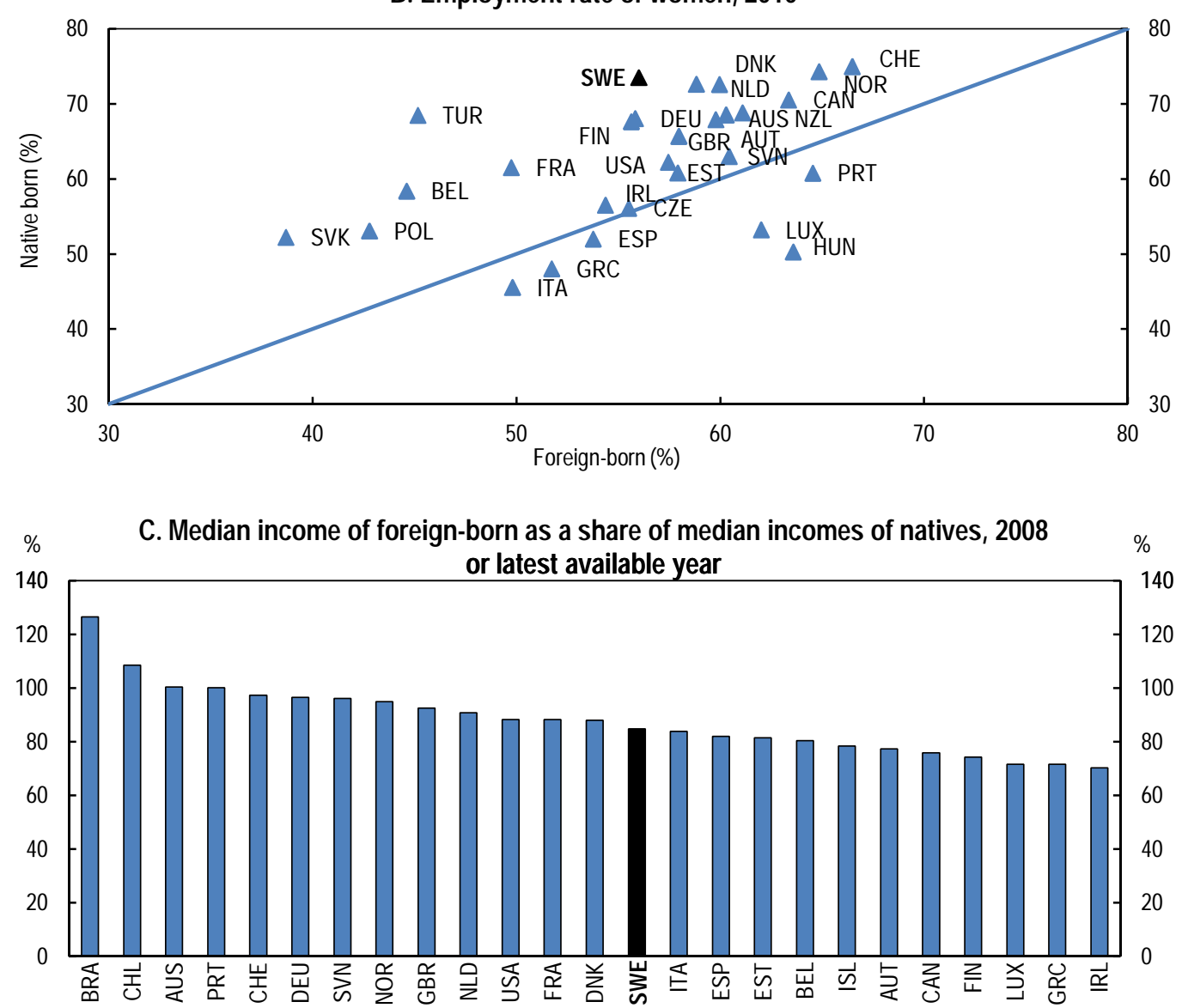

Source: OECD, International Migration Database. 
Labour market outcomes vary greatly between different types of immigrants. Those coming from outside the European Union and through the family and asylum channels, who made up more than $70 \%$ of immigrant flows between 2006 and 2008, are less educated and younger than the natives, which make them more likely to suffer from labour market exclusion (OECD, 2011b, Table 4). By contrast, non-EU migrants who come through the labour channel are more educated than the natives, have a higher income and a very low unemployment rate. In 2008, Sweden reverted to a more open labour migration policy by allowing employers to recruit workers from abroad for any occupation as long as wages and other working conditions fulfil the ones prevailing in collective agreements. This boosted the number of non-EU migrants coming in through the labour channel.

Table 4. Characteristics of permanent residents by migration channel

2009

\begin{tabular}{|c|c|c|c|c|c|c|c|}
\hline & \multicolumn{2}{|c|}{ Country of birth } & \multicolumn{5}{|c|}{ Migrant type (non-EU) } \\
\hline & $\begin{array}{l}\text { Native- } \\
\text { born }\end{array}$ & $\begin{array}{l}\text { Foreign- } \\
\text { born }\end{array}$ & Labour & Family & Asylum & Study & Other \\
\hline Age & 40.5 & 40.7 & 35.7 & 33.7 & 35.2 & 28.9 & 38.1 \\
\hline Women & $49 \%$ & $51 \%$ & $24 \%$ & $59 \%$ & $37 \%$ & $30 \%$ & $39 \%$ \\
\hline Low education & $20 \%$ & $25 \%$ & $4 \%$ & $33 \%$ & $43 \%$ & $0 \%$ & $24 \%$ \\
\hline High education & $26 \%$ & $30 \%$ & $80 \%$ & $33 \%$ & $24 \%$ & $67 \%$ & $41 \%$ \\
\hline Total annual income (SEK) & 254535 & 180455 & 327174 & 84236 & 67670 & 34062 & 130843 \\
\hline Registered employment & $73 \%$ & $53 \%$ & $65 \%$ & $33 \%$ & $25 \%$ & $14 \%$ & $44 \%$ \\
\hline Registered unemployment & $4 \%$ & $13 \%$ & $1 \%$ & $22 \%$ & $47 \%$ & $4 \%$ & $12 \%$ \\
\hline $\begin{array}{l}\text { Memorandum item: } \\
\text { Population type as a share } \\
\text { of total population }\end{array}$ & $83.6 \%$ & $16.4 \%$ & $0.1 \%$ & $1.7 \%$ & $1.0 \%$ & $0.2 \%$ & $0.0 \%$ \\
\hline
\end{tabular}

Note: Permanent residents in Sweden aged 16 to 65. Migrants include only those arrived prior to 2009.

Source: OECD (2011), Recruiting Immigrant Workers: Sweden, Paris.

\section{The disabled and sick}

In all countries, people with a disability are exposed to the risk of being excluded from the labour market. In Sweden, the share of the working age population receiving sickness and disability has remained among the highest in the OECD for decades. Nevertheless, the employment rate of people with disability was the highest in the OECD in the late 2000s and the gap in employment rates between people with and without disability was relatively small (Figure 11). The labour market outcomes for workers with mental health problems are less favourable, particularly for those with severe disorders (OECD, 2011c). While the relatively generous welfare system prevents recipients of disability benefits from falling into relative poverty, it may also act as a trap and foster feelings of exclusion. 
Figure 11. Employment rates of people with disability and mental health problems
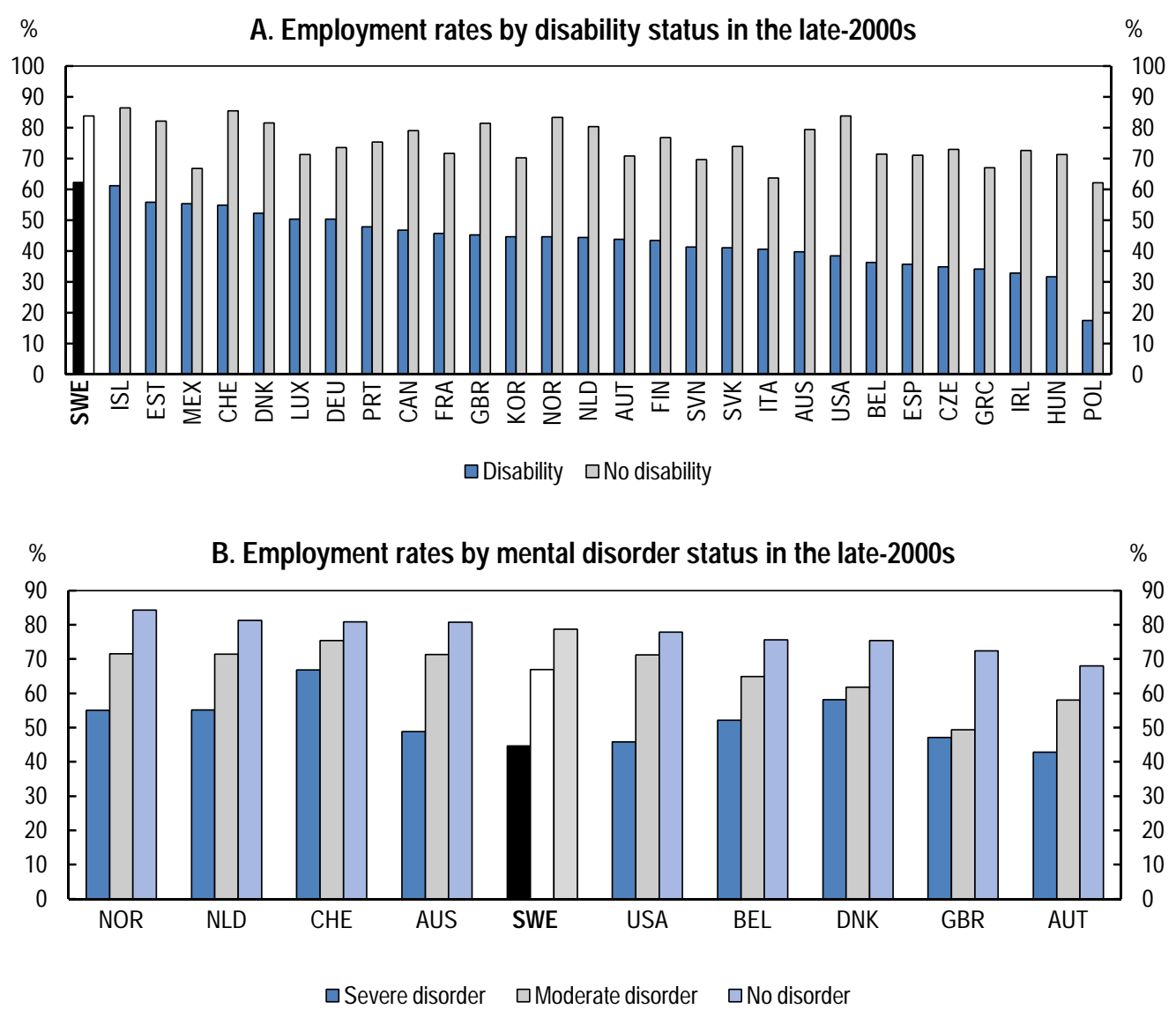

Note: In Panel B, data for the United Kingdom refer to England only.

Source: OECD (2010), Sickness, Disability and Work: Breaking the Barriers - A Synthesis of Findings across OECD Countries, Paris; OECD (2011), Sick on the Job? Myths and Realities about Mental Health and Work, Paris.

Since 2006, Sweden has undertaken a series of reforms to address the long-term structural problems associated with its sickness and disability policies. A new sick-leave process was introduced with stricter time limits for work-capacity assessment at different stages (with referral to other jobs in the same company after three months and to all jobs in the labour market after six months) to facilitate early return to work. Moreover, sickness benefits can now be paid for 2.5 years at most while there was no limit in the previous system. Entitlement criteria for a disability pension have also been made more stringent. These reforms have reduced the inflows into the sickness and disability benefit schemes and the stock of benefit recipients (Figure 12), although sickness benefit claims were on the rise in late 2012. Even so, the reforms entail new challenges: social and labour market institutions have to adapt to help people with a disability find a job and durably escape exclusion. 
Figure 12. Evolution of the stock of recipients of sickness and disability benefits

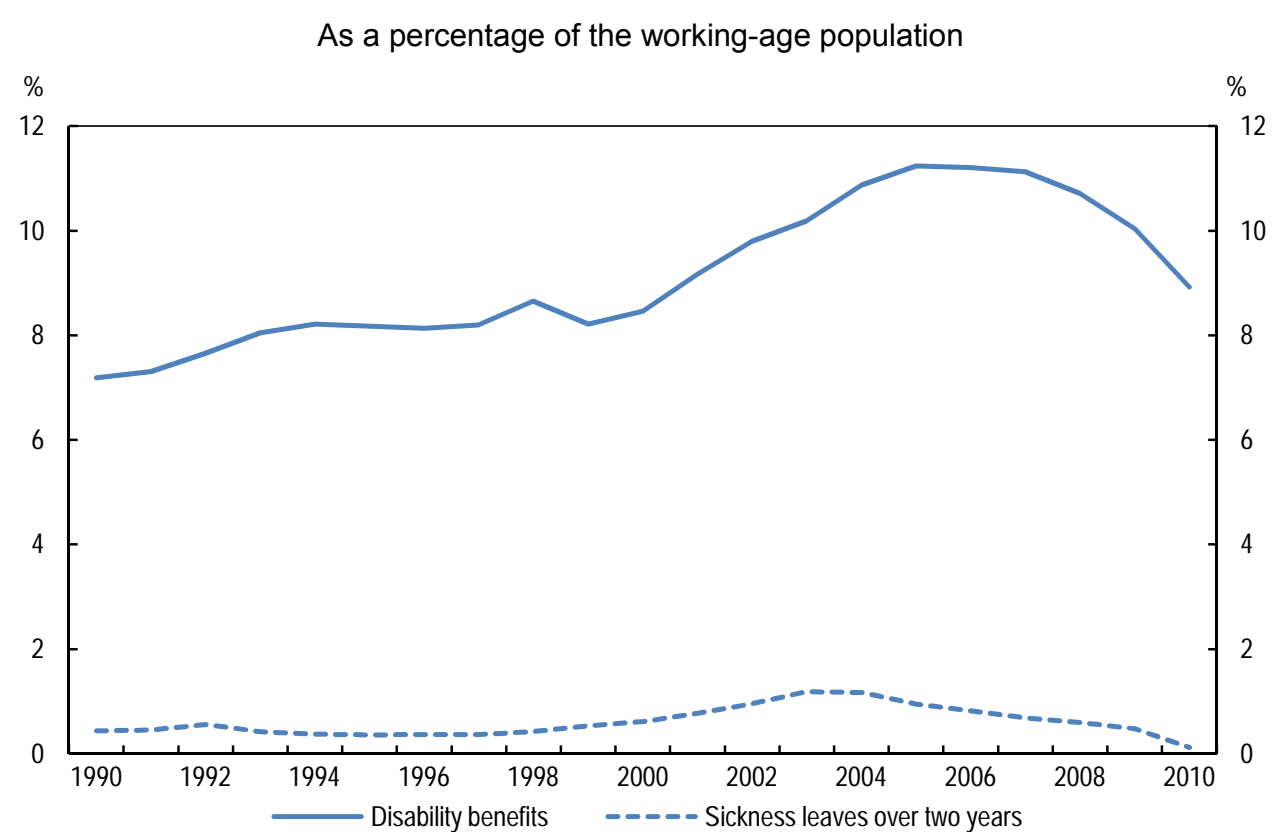

Source: OECD (2010), Sickness, Disability and Work: Breaking the Barriers - A Synthesis of Findings across OECD Countries, Paris.

\section{Women}

Sweden performs well in terms of gender equality. Educational attainment of women, labour force participation and employment rates for women are high in Sweden (Figure 13). The widespread availability of affordable childcare enables women to work full-time, and the share of part-time employment for women is below the OECD average. However, despite higher labour force participation and employment rates the share of female managers is slightly below the OECD average. The contrast between the public and the private sector is striking, with the share of women in management positions in the public sector at $58 \%$ in 2006, compared to $23 \%$ in the private sector (Statistics Sweden, 2008). 
Figure 13. Female labour market outcomes
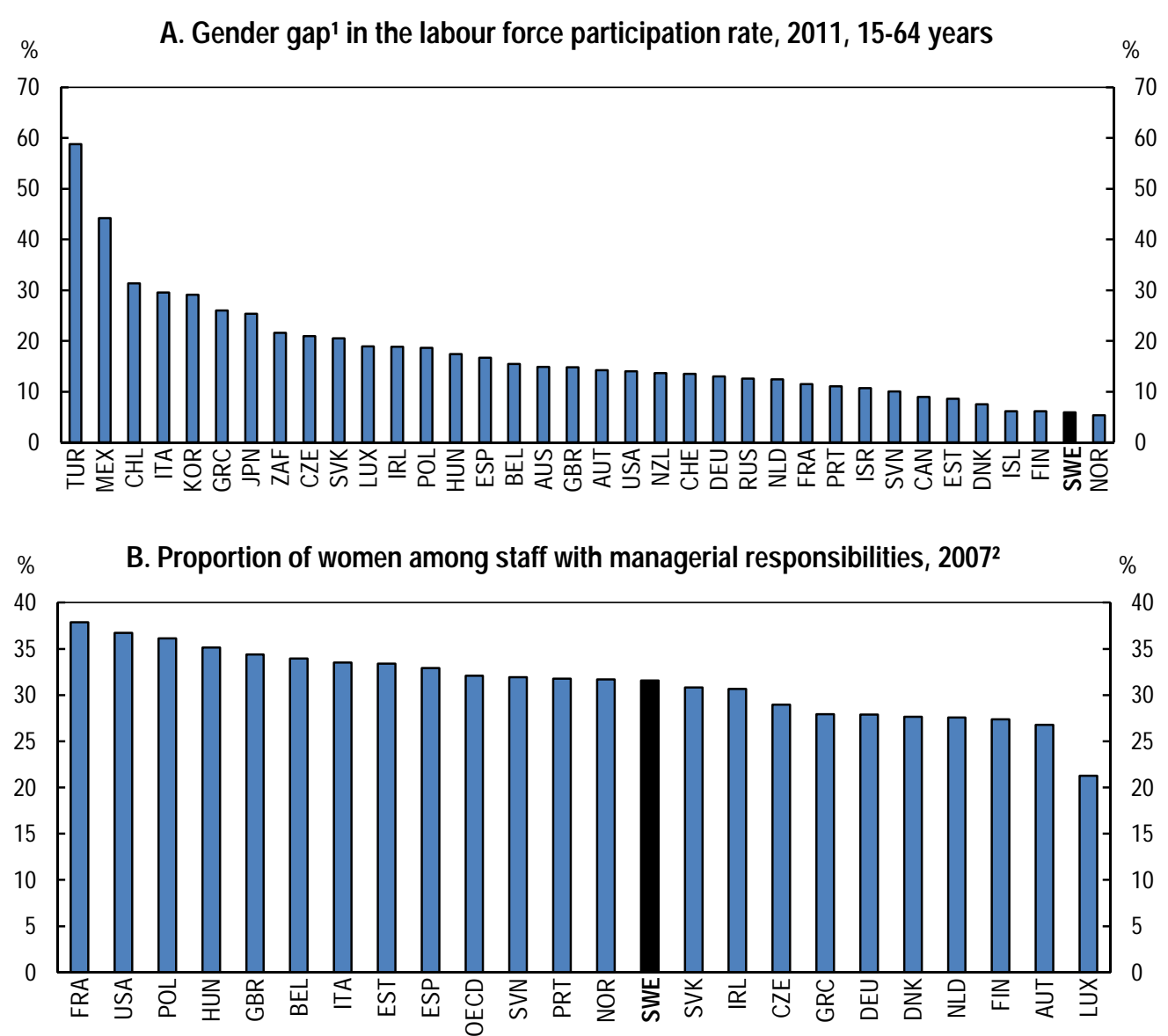

1. Difference between male and female labour force participation rate.

2. March 2009 for the United States.

Source: OECD, Employment Database; European Labour Force Survey, 2007, and Current Population Survey, March 2009, for the United States.

Although slightly less than the OECD average, the gender wage gap for median earners only declined by $4 \%$ in Sweden between 2000 and 2010, while it declined more in some countries with a similar gender wage gap in 2000. The compressed wage structure and relatively high minimum wage tend to contain wage inequality and the gender wage gap (Blau and Kahn, 2003; Magnusson, 2010). For the top decile of the earnings distribution, this gap stands at $25 \%$, exceeding the $21 \%$ OECD average. For the bottom decile, the gap is $9 \%$ and $13 \%$ for Sweden and the OECD, respectively (Figure 14). Even when differences in occupation and sectors are controlled for, a "glass ceiling" is observed (Albrecht et al., 2003; Arulampalam et al., 2007). OECD estimates show that in Sweden as in most other OECD countries, hours worked and job characteristics are the main contributors to this gap, apart from unexplained factors (Figure 15). 
Figure 14. The glass ceiling
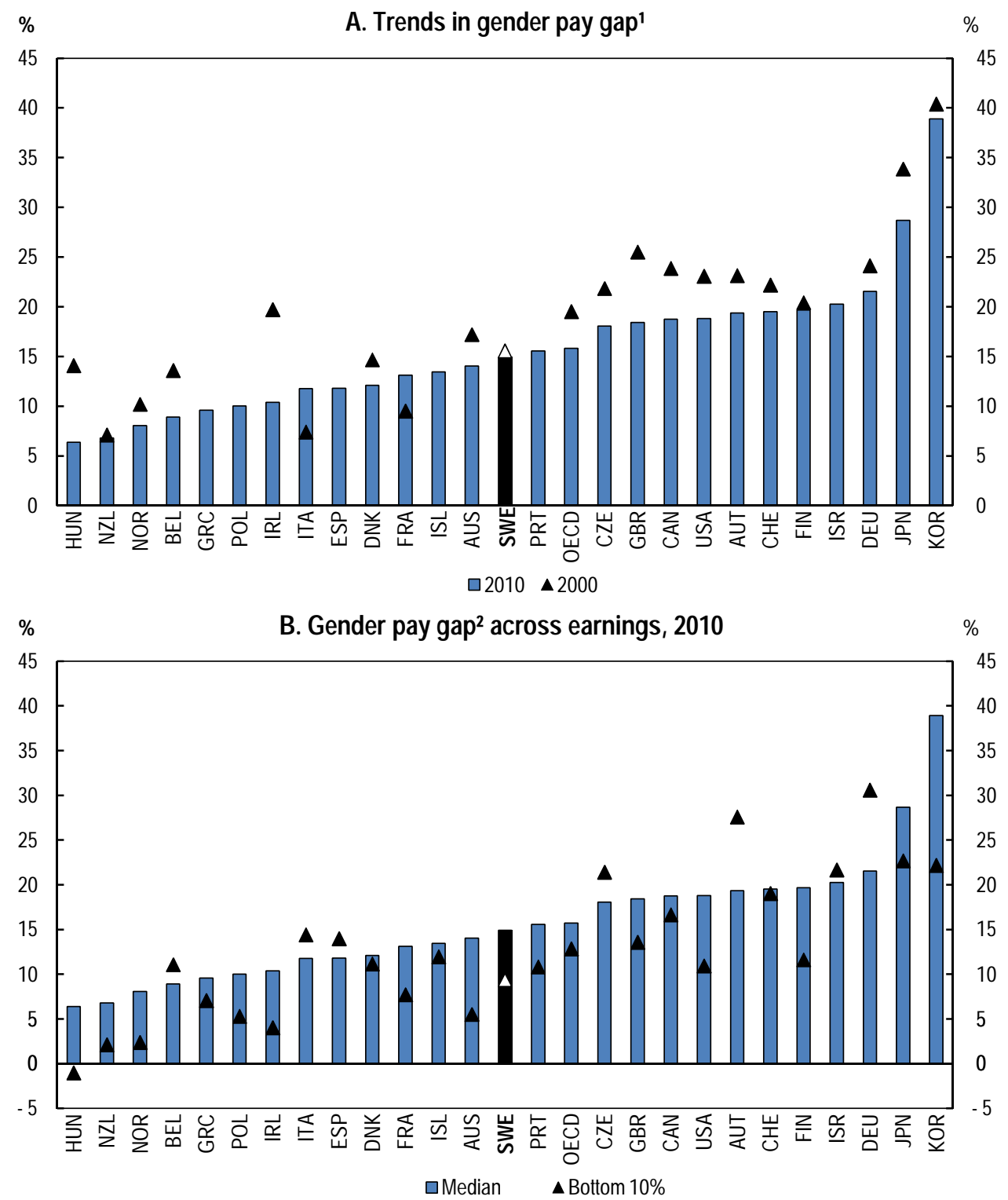

1. Defined as the difference between male and female median wages divided by male median wages. Data refer to 2009 (instead of 2010) for Ireland, Denmark, Sweden, the Czech Republic, Austria, Switzerland, Finland, Israel, Germany, Korea and to 2008 for Belgium, France, Greece, Iceland, Italy, Poland, Portugal, Spain. Data refers to 1999 (instead of 2000) for the Czech Republic.

2. Defined as the difference between male and female wages divided by male wages.

Source: OECD, Employment Database. 
Figure 15. Main determinants of the gender pay gap in OECD countries

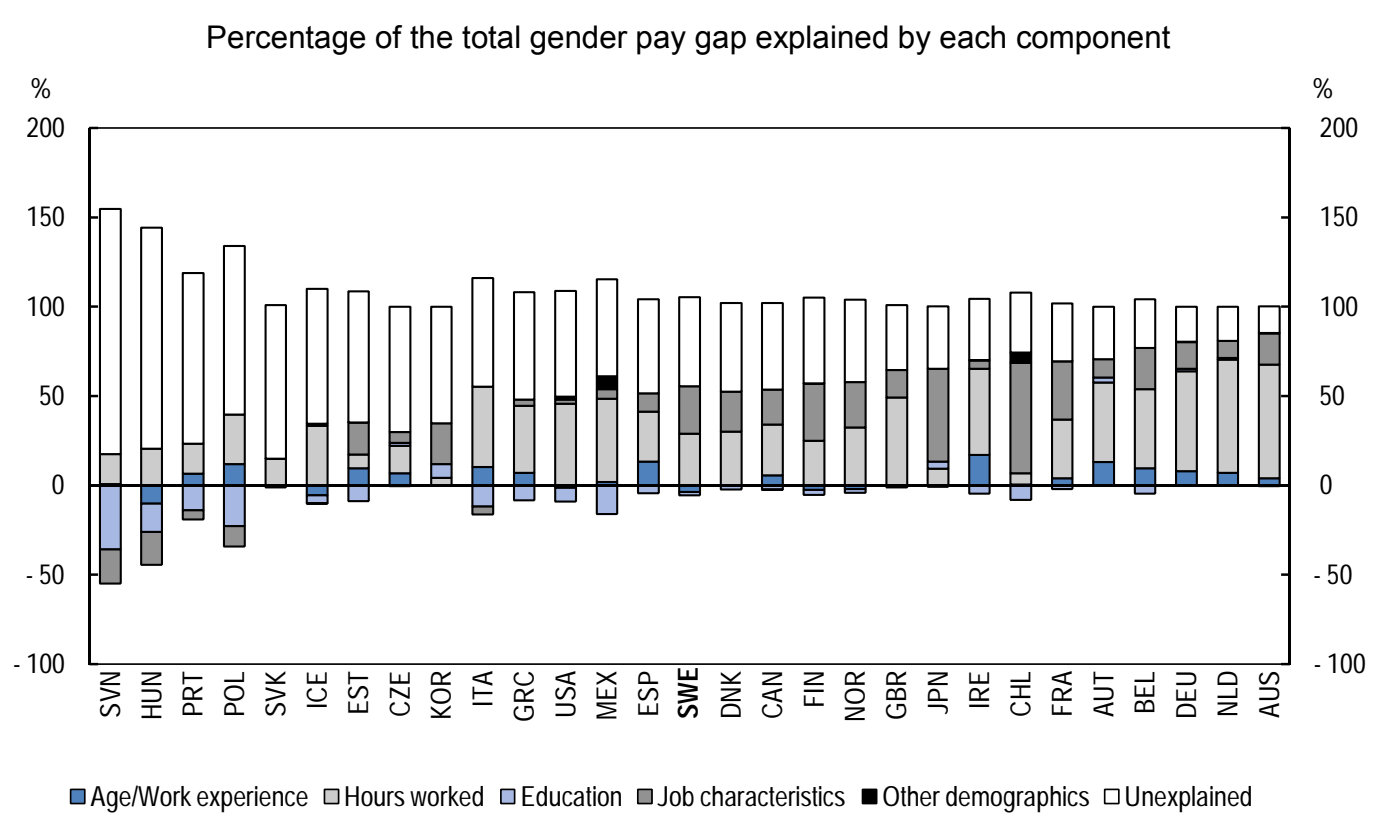

Note: The wage gap is computed on annual earnings of both part-time and full-time employees (excluding self-employed individuals). Countries are ordered by decreasing proportion of unexplained gender pay gap.

Source: OECD (2012), Closing the Gender Gap: Act Now, Paris.

Women are over-represented in some occupations. In the 1990s, the development of new technologies and changes in work organisation were expected to contribute to widening women's occupational choices, but female employment is concentrated in fewer occupations, and this "horizontal segregation" has not improved over time (Kumlin, 2007). A comparison of the number of occupations that account for half of the employed men and women shows that Sweden is one of the countries with the widest gap in occupational concentration according to the OECD's Gender Report (OECD, 2012c; Figure 16, Panel A). Women are also more represented in the public sector. In 2008, the share of women in the public sector was $73 \%$ in Sweden, compared to $58 \%$ in an average of selected OECD countries (Figure 16, Panel B).

The concentration of female employment in the public sector and therefore in a small number of activities has contributed to maintaining the gender wage gap. Although part of the difference can be explained by preferences, concentration in fewer occupations may curtail women's employment opportunities and prevent them from making the most of their skills. More flexible working hours and parttime employment opportunities in the public sector help to achieve a balance between work and family lives. However, they may also explain why fewer women attain high-paying positions in the private sector (Mandel and Semyonov, 2005). 
Figure 16. Concentration of female employment in certain sectors
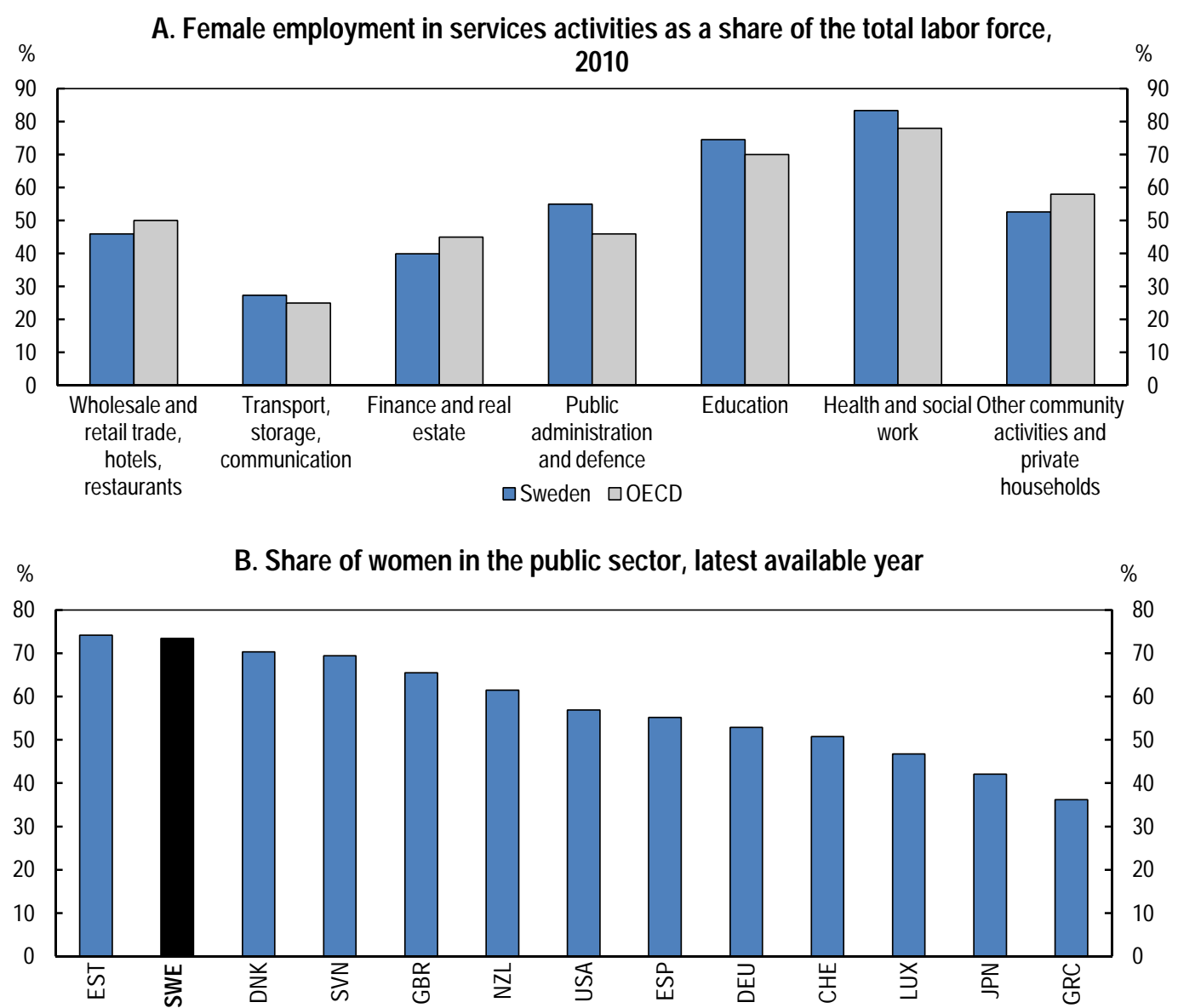

Source: OECD (2012), Gender Equality in Education, Employment and Entrepreneurship, Final Report to the MCM, Paris; ILO.

\section{Older workers}

In many OECD countries, older workers are at greater risk of labour market exclusion and poverty. These risks are relatively low in Sweden as their labour force participation and employment rates are well above the OECD average. The employment rate of 60 to 64 -year olds was $63 \%$ in 2011, as against $43 \%$ OECD-wide. The unemployment rate of this group, at 4.8\%, was also below the OECD $5.6 \%$ average. However, the risk of becoming long-term unemployed is higher for this group. Furthermore, the hiring rates of workers over 55 were below the OECD average in 2011, suggesting low labour mobility for this age group of workers (OECD, 2012d).

\section{The earned-income tax credit provides stronger incentives to participate in the labour market}

The earned-income tax credit (EITC) has been a key pillar of Sweden's labour market policies in recent years. It provides strong incentives to take a job and thereby reinforces the positive impact of structural reforms (such as the reform of the sickness and disability benefit schemes) on employment, while limiting the increase in income inequalities. The Swedish EITC was introduced in 2007 and enlarged in 2008, 2009 and 2010. Individuals aged below 65 all face the same tax credit formula and those older than 65 a more generous one. There is no need to apply for the scheme; taxes are automatically reduced. The formula is independent of marital status or number of children and cannot lead to a reduction of tax liability below zero. The Swedish EITC is not phased out, which avoids increasing marginal tax rates that 
are already high for higher incomes. However, the tax credit is capped, which implies that, as a share of income, it tends to zero for high incomes. The system is costly, at 2.3\% of GDP in 2011.

There is a vast literature on the impact of in-work tax policies. Making-work-pay policies have two main goals: raising employment and limiting in-work poverty. However, these policies have been mainly assessed in terms of job creation while a more comprehensive assessment would have to take into account their impact on inequalities. Empirical evidence tends to show that the positive effects on headcount employment outweigh the costs associated with reduced incentives to work more hours (Immervoll and Pearson, 2009). Evaluations have mainly concerned periods of buoyant labour demand, which raises the question of how effective these policies are in an economic downturn, when wages need to adjust downwards if additional jobs are to be forthcoming. Even so, an EITC can still be effective as a tool to reduce in-work poverty in times of crisis.

Several factors determine the size of the potential positive impact of the EITC on employment:

- The shape of the income distribution prior to its introduction: with a narrow income distribution, as in Sweden, it is difficult to target and finance the EITC.

- When the existing tax burden is high, redistribution policies such as the EITC are more expensive as the additional taxes needed to finance transfers are likely to exacerbate disincentive problems.

- The potential to increase work incentives and in-work incomes is larger where wages of potential recipients are low.

Compared with some other countries, the size of the effect is expected to be smaller in Sweden because of the country's wage formation and distribution characteristics (Bassanini et al., 1999). Studies that have assessed the impact of the Swedish EITC on employment have yielded mixed results. On the one hand, ex-ante studies tend to find a positive impact on employment with the size of the effects depending on the model and underlying assumptions (Swedish Ministry of Finance, 2012a). Ministry of Finance estimates suggest that the EITC could increase employment by $2.3 \%$. However, the absence of a "control" group - since all individuals with a job receive the EITC - makes it very difficult to evaluate its effect on employment through quasi-experimental or ex-ante methods. One study assesses the impact of the EITC up to 2008 by using the differences in the EITC received by similar individuals in different municipalities, stemming from the fact the EITC amount depends on the local tax rate, which varies across municipalities (Edmark et al., 2012). However, this source of variation is too small to robustly establish the impact of the EITC. Two other studies use the fact that the EITC is higher for workers older than 65 and find a positive impact on employment for this age group (Swedish Ministry of Finance, 2012b; Laun, 2012).

While it may be too early to fully assess the impact of the Swedish EITC, existing studies point to a number of policy-relevant conclusions:

- The EITC has likely helped to contain the risk of poverty by raising the income of workers. However, it may have only partly delivered its effect on employment as labour demand has been subdued lately. Nevertheless, it may have contributed to the fall in unemployment between mid2009 and mid-2011. It may also have helped reduce the number of recipients of sickness and disability benefits.

- More flexibility in wage setting, especially at the lower end of the wage spectrum, would enable the EITC to fully deliver its benefits in terms of both employment and reduction of inequalities (see below).

- The absence of the phasing out of the EITC when incomes increase raises the cost of the system. 


\section{Entry thresholds in the labour market are high for some groups of workers}

Minimum wages and job protection legislation protect workers against the risks of in-work poverty and abusive dismissals. However, they can also hinder the entry of low-educated and inexperienced workers into the labour market and limit their access to jobs where they would be able to accumulate human capital. Therefore, minimum wages and job protection legislation need to find the right balance between protecting workers and easing the entry of new workers into the labour market.

Figure 17. Trade union density and collective bargaining coverage 1990 and latest year
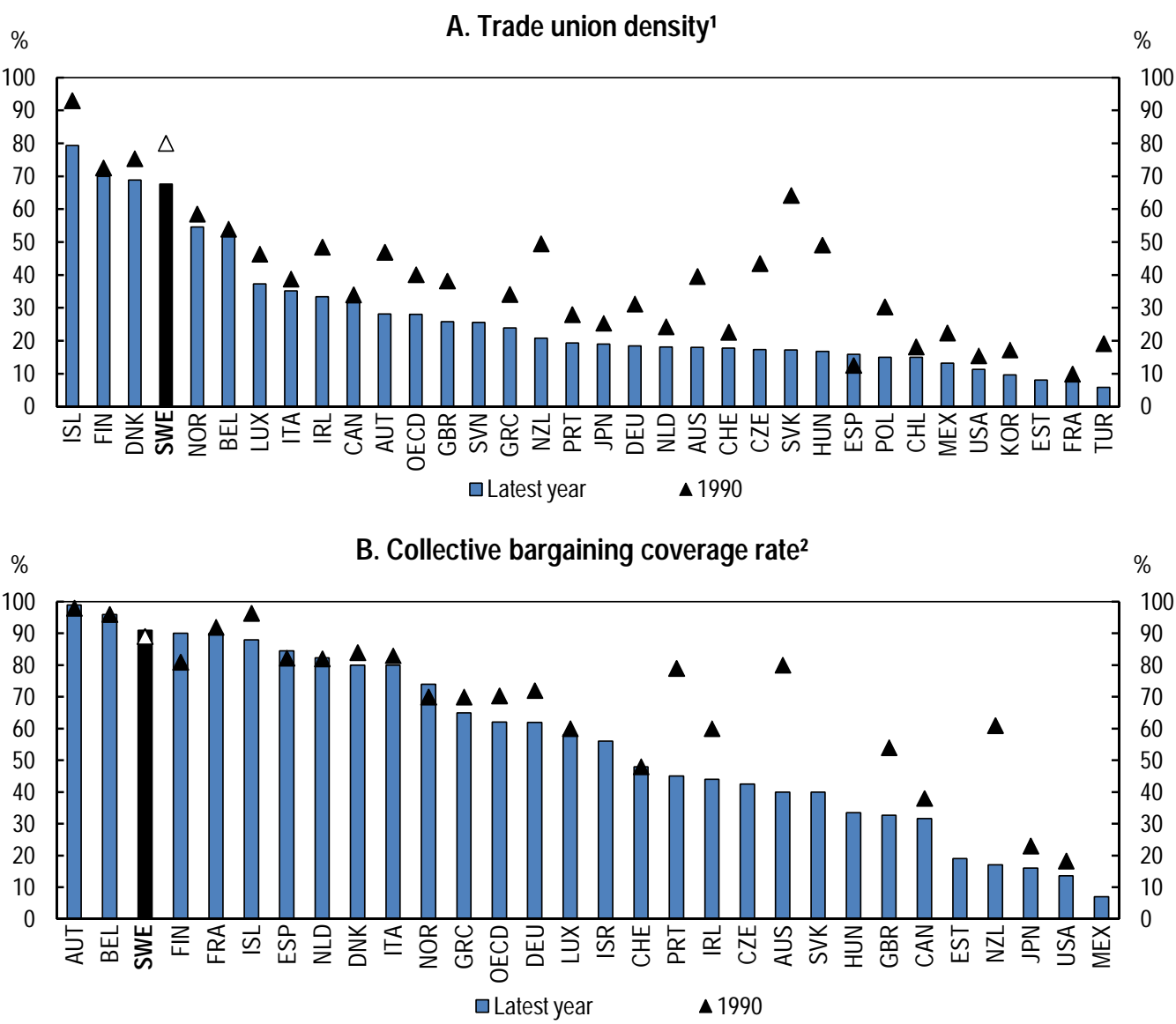

Note: Trade union density refers to the number of trade union members as a percentage of wage and salary earners; the collective bargaining coverage rate refers to the number of workers covered by wage bargaining agreements as a proportion of all wage and salary earners (employees excluded from bargaining rights have been removed from the numerator and the denominator).

1. Data for the latest year refer to 2011 for: Australia, Canada, Ireland, Japan, Mexico, the Netherlands, New Zealand, Norway, Sweden, the United Kingdom and the United States; 2010 for Austria, Chile, Estonia, Finland, Germany, Italy, Korea, Poland, Portugal and Turkey; 2009 for Belgium, the Czech Republic, Denmark, Slovenia and Switzerland; and 2008 for France, Greece, Hungary, Iceland, Luxembourg and the Slovak Republic. Data refer to 1995 instead of 1990 for Czech Republic and Hungary; 1992 for Mexico, and 1994 for the Slovak Republic.

2. Data for the latest year refer to 2009 for Austria, Canada, the Czech Republic, Estonia, Germany, Italy, Portugal, the Slovak Republic, the United Kingdom and the United States; 2008 for Belgium, France, Greece, Iceland, Ireland, Japan, Luxembourg, Mexico, the Netherlands, Norway, Spain, Sweden and Switzerland; and 2007 for Australia, Denmark, Finland and New Zealand. Data refer to 1991 instead of 1990 for Sweden and Switzerland; 1989 for Iceland. As data for the Czech Republic, Hungary, Israel, Mexico and the Slovak Republic are available for the latest year only, these countries are not included in the OECD average.

Source: OECD Database on Trade Unions; Visser, J. (2011), "Data Base on Institutional Characteristics of Trade Unions, Wage Setting, State Intervention and Social Pacts”, 1960-2010(ICTWSS), Version 3.0, May, www.uva-aias.net/208. 


\section{The minimum wage}

Wage setting has become increasingly decentralised, allowing wages to better adjust to productivity (Ahlberg and Bruun, 2005; OECD, 2012e). In several cases, the determination of average wage increases still takes place at the sectoral level and most workers are still covered by collective agreements (Figure 17), but the decision on how to distribute wage increases among employees is left to firm-level bargaining. As a result, wages have become much more individualised, though still within a collective framework.

Minimum wages are still set at the sector level through collective agreements although they are differentiated by age, experience, and occupation. Employer contributions also add to the minimum cost of labour. As a result, the relative minimum labour cost for a prototype worker is largely above the average in OECD countries with a legal minimum wage, although in Sweden, not all workers are covered by a minimum wage (Figure 18). The minimum wage was $76 \%$ and $85 \%$ of the average wage in the retail sector and in the hotel and restaurant sectors, respectively, in 2010, suggesting that a large share of the workers are paid at the minimum wage in these sectors, with the minimum wage being binding.

Figure 18. Relative minimum cost of labour ${ }^{1}$ in OECD countries

Minimum cost of labour as a share of the labour cost for the median wage, 2010

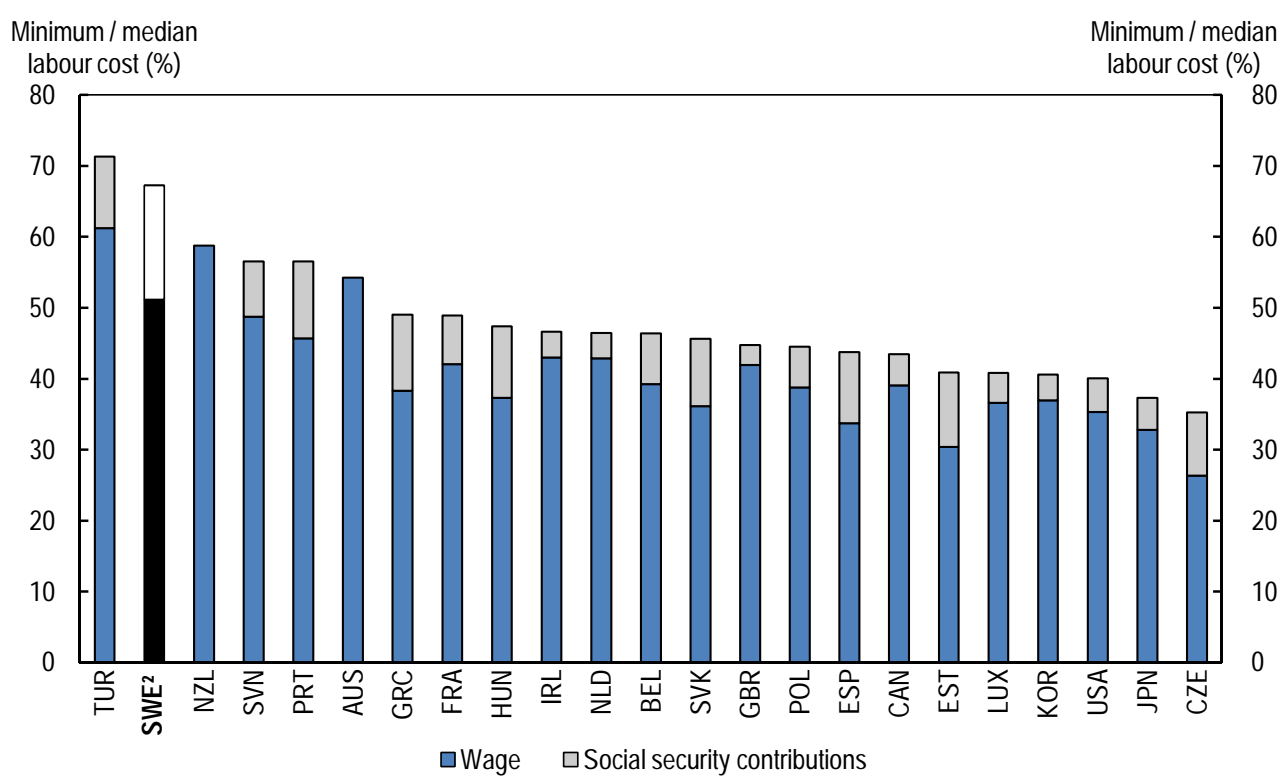

1. The cost of labour is the sum of the wage level and the corresponding social security contribution paid by employers.

2. Apart from Sweden, only countries with a legal minimum wage are shown. The minimum wage for Sweden is computed for a 20 -year old worker, with no work experience, who has an unskilled job in a non-metropolitan region. Since the minimum wage for such a "prototype worker" varies between sectors, the figure shows the minimum wage in the sector where it is the lowest (the engineering sector).

Source: OECD, Labour Force Statistics; Skedinger, P. (2007), "The Design and Effects of Collectively Agreed Minimum Wages: Evidence from Sweden", IFN Working Paper, No. 700; Statistic Sweden and OECD calculations.

For some groups of workers, the minimum cost of labour has been lowered by cuts in social contributions and by public subsidies. Social contributions for younger workers have been lowered from $31.4 \%$ to $15.5 \%$. For immigrants benefiting from special programmes, public subsidies can amount from $70 \%$ to $85 \%$ of the labour cost. Nevertheless, the minimum cost of labour can hamper access to the labour market for young workers with a low level of education and low-productivity workers who are not eligible 
to subsidised jobs. Increases in the minimum wage, which have been substantial in the hotel and restaurant and retail sectors since 1995, tend to spill over to other low wages. Empirical evidence is limited but one study suggests that the minimum wage has had negative effects on employment in the service sector (Skedinger, 2006).

The wage setting system rests on negotiations between employee and employer confederations and the government rarely intervenes. This has delivered some good results by, for instance, allowing wages and hours to fall in the manufacturing sector during the crisis, which has limited the impact of the crisis on unemployment. More recently, the government has proposed a "Job Pact" with unions and employers to tackle youth unemployment (EIRO, 2012, Annex 1). The "Job Pact" is inspired by agreements reached in 2010 in the metal industry to employ young workers on contracts that include $75 \%$ of the time on the job and $25 \%$ of the time in education with compensation equal to $75 \%$ of the minimum wage. These initiatives are welcome and the government should continue working with social partners to develop and expand these types of contracts. In parallel, the government should commission and publish regularly studies on the impact of minimum wages on employment. Over the longer term, there should be broader possibilities to hire less-productive workers at a lower relative minimum wage. The EITC would tackle the potential adverse impact of a lower relative minimum wage on inequalities. Another option would be to lower social contributions for the groups at risk, thereby further lowering their labour cost. However, this would not address the core of the problem and could be costly.

\section{Job protection legislation}

The flexibility of the Swedish labour market mainly comes from temporary contracts, which employers can use with few constraints. By contrast, the legislation on permanent contracts, which mainly protects insiders, is stricter, with heavy notification procedures in case of dismissal, stringent regulation of the order of layoffs in case of redundancy, a relatively broad definition of unfair dismissals and sizeable compensation following unfair dismissal (OECD, 2011d). When cases go to court, the procedures are long (one to two years), which may explain why the number of cases is relatively low (Skedinger, 2010). Accordingly, the gap in the strictness of employment protection legislation (EPL) between permanent and temporary contracts, as measured by OECD EPL indicators, is among the highest in the OECD (Figure 19).

There is a rich literature on the effects of EPL (OECD, 2006; Skedinger, 2010). Different groups are not affected in the same way by EPL. Strict EPL for permanent jobs has negative employment effects for vulnerable groups (OECD, 2006). Vulnerable groups are more likely to be on temporary jobs, and, when there is an asymmetry in the legislation between temporary and permanent contracts, are more likely to be hit harder by job destructions in times of crisis. They are also less likely to get training (Wallette, 2005) and earn less than workers with similar characteristics on permanent contracts (OECD, 2012f). These factors create some duality in the labour market, contributing to inequality.

Collective agreements provide options to deviate from the legal framework through both more and less restrictive regulations. In particular, it is possible to deviate from the "last-in-first-out" rule through collective agreement and to agree on which workers to dismiss when there are redundancies. However, this does not ensure that the agreement will be an efficient outcome. It may penalise workers who are less integrated or less represented by unions such as youth and immigrants. Moreover, while collective agreements introduce some flexibility in the use of permanent contracts, the share of temporary contracts is relatively large in Sweden, which suggests that collective agreements do not fully remove the asymmetry in EPL between temporary and permanent contracts. Youth and those with limited formal education are more likely to hold temporary jobs (Figure 20) and have endured greater job losses during the crisis. 
Figure 19. Job protection legislation and temporary contracts
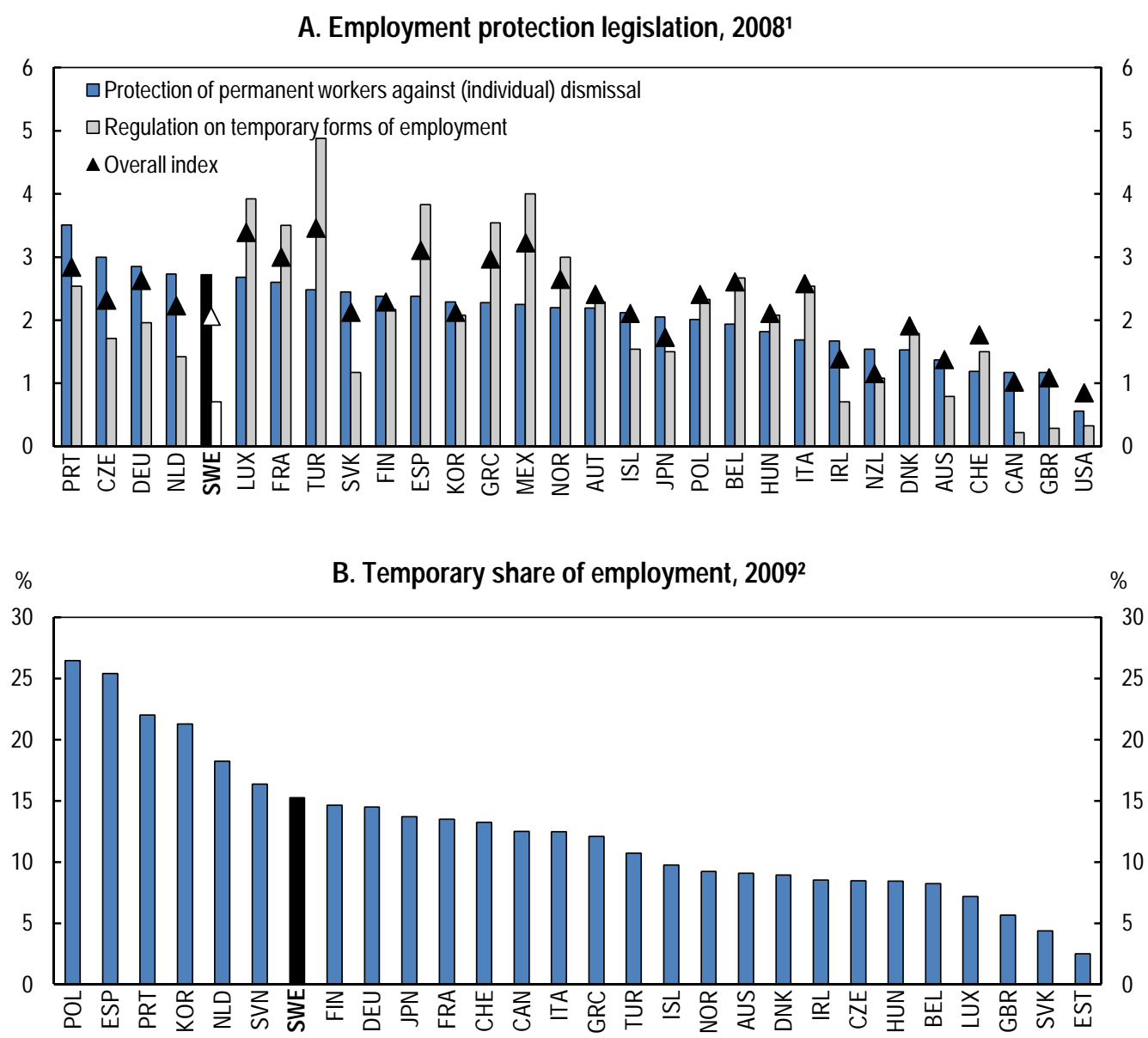

1. Latest available OECD indicator for strictness of employment protection legislation. Index scale is 0 to 6 , from least to most restrictive.

2. Incidence of temporary employment as a share of total dependent employment, latest available observation.

Source: OECD, Employment Protection Database; OECD, Labour Force Statistics.

Labour market duality is less marked than in several other EU countries. On average, after one year, $41 \%$ of temporary workers in Sweden find a permanent job (Table 5). However, the probability of moving from a temporary job to unemployment is higher in Sweden than in many other EU countries. Furthermore, temporary jobs have tended to become increasingly concentrated on the more fragile groups of workers, such as youth and non-EU immigrants, raising the risk that duality becomes a larger problem in the future. In $2011,66 \%$ of non-EU immigrant workers aged 15 to 24 were on these contracts, up from $50 \%$ a decade earlier. In most EU countries, transitions from temporary to permanent jobs are more difficult for youth, the low educated and women (Figure 21). In the case of Sweden, education plays a major role, as confirmed by new empirical analysis showing how age, education and gender influence transitions (Box 3). According to these estimates, having a secondary degree would raise the probability of getting a permanent contract by almost $70 \%$. 
Figure 20. Characteristics of workers with temporary jobs ${ }^{1}$ 2011

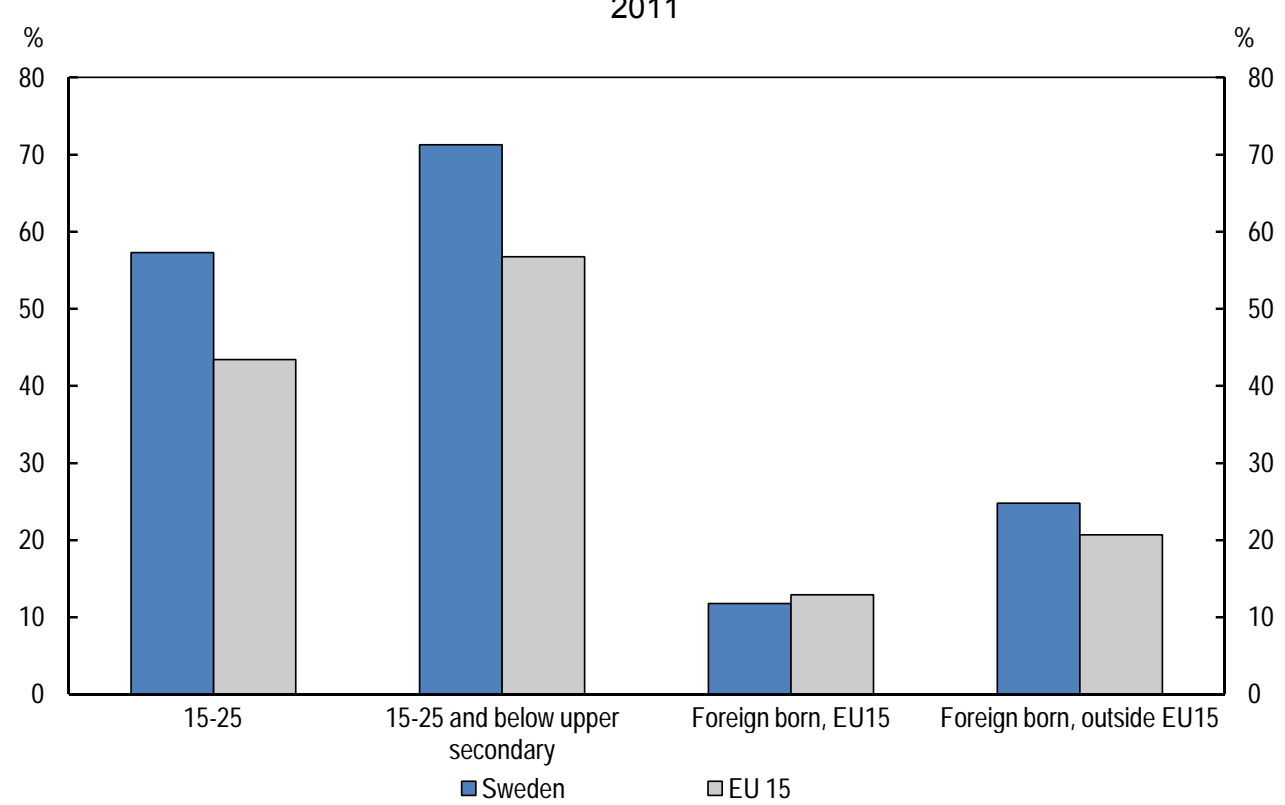

1. Temporary employees as percentage of the total number of employees.

Source: Eurostat.

Table 5. One-year mobility of temporary workers

In per cent

\begin{tabular}{l|cccc}
\hline \multicolumn{5}{c}{ Temporary workers moving into: } \\
\hline & $\begin{array}{c}\text { Permanent } \\
\text { job }\end{array}$ & Unemployment & $\begin{array}{c}\text { Temporary } \\
\text { job }\end{array}$ & Others \\
\hline Slovak Republic & 52.4 & 6.1 & 32.6 & 9.0 \\
Hungary & 46.9 & 11.0 & 25.0 & 17.0 \\
United Kingdom & 45.1 & 2.5 & 28.9 & 23.5 \\
Norway & 43.5 & 4.9 & 36.7 & 14.9 \\
Austria & 41.6 & 5.6 & 30.8 & 21.9 \\
Sweden & 41.2 & 10.4 & 36.3 & 12.0 \\
Luxembourg & 40.1 & 10.4 & 40.7 & 8.7 \\
Slovenia & 38.8 & 9.6 & 43.3 & 8.3 \\
Ireland & 38.1 & 7.4 & 35.3 & 19.2 \\
Czech Republic & 37.3 & 5.0 & 48.3 & 9.4 \\
Belgium & 35.8 & 8.4 & 42.8 & 12.9 \\
Italy & 29.7 & 8.1 & 47.0 & 15.2 \\
Poland & 26.9 & 8.9 & 54.7 & 9.5 \\
Iceland & 24.7 & 2.6 & 38.2 & 34.5 \\
Germany & 23.0 & 0.7 & 53.9 & 22.4 \\
Netherlands & 22.9 & 1.6 & 65.5 & 10.0 \\
Spain & 22.6 & 14.0 & 49.4 & 13.9 \\
Greece & 21.4 & 9.1 & 59.1 & 10.3 \\
Portugal & 21.0 & 11.4 & 57.0 & 10.7 \\
Finland & 20.3 & 9.9 & 48.0 & 21.8 \\
France & 13.8 & 9.2 & 71.6 & 5.4 \\
\hline Average & $\mathbf{2 9 . 0}$ & $\mathbf{9 . 1}$ & $\mathbf{4 9 . 5}$ & $\mathbf{1 2 . 4}$ \\
\hline
\end{tabular}

Note: Probabilities of transition within one year from a temporary job, over 2003-09. For instance, the probability of transition from a temporary to a permanent job is calculated as the number of persons who were in a temporary job in one year and in a permanent job the year after divided by all transitions.

1. Includes self-employed, students or others inactive.

Source: SILC Longitudinal Database and OECD calculations. 
Figure 21. Characteristics influencing the mobility of temporary workers to permanent jobs

Gap in the probability of transition between specific groups and the overall population

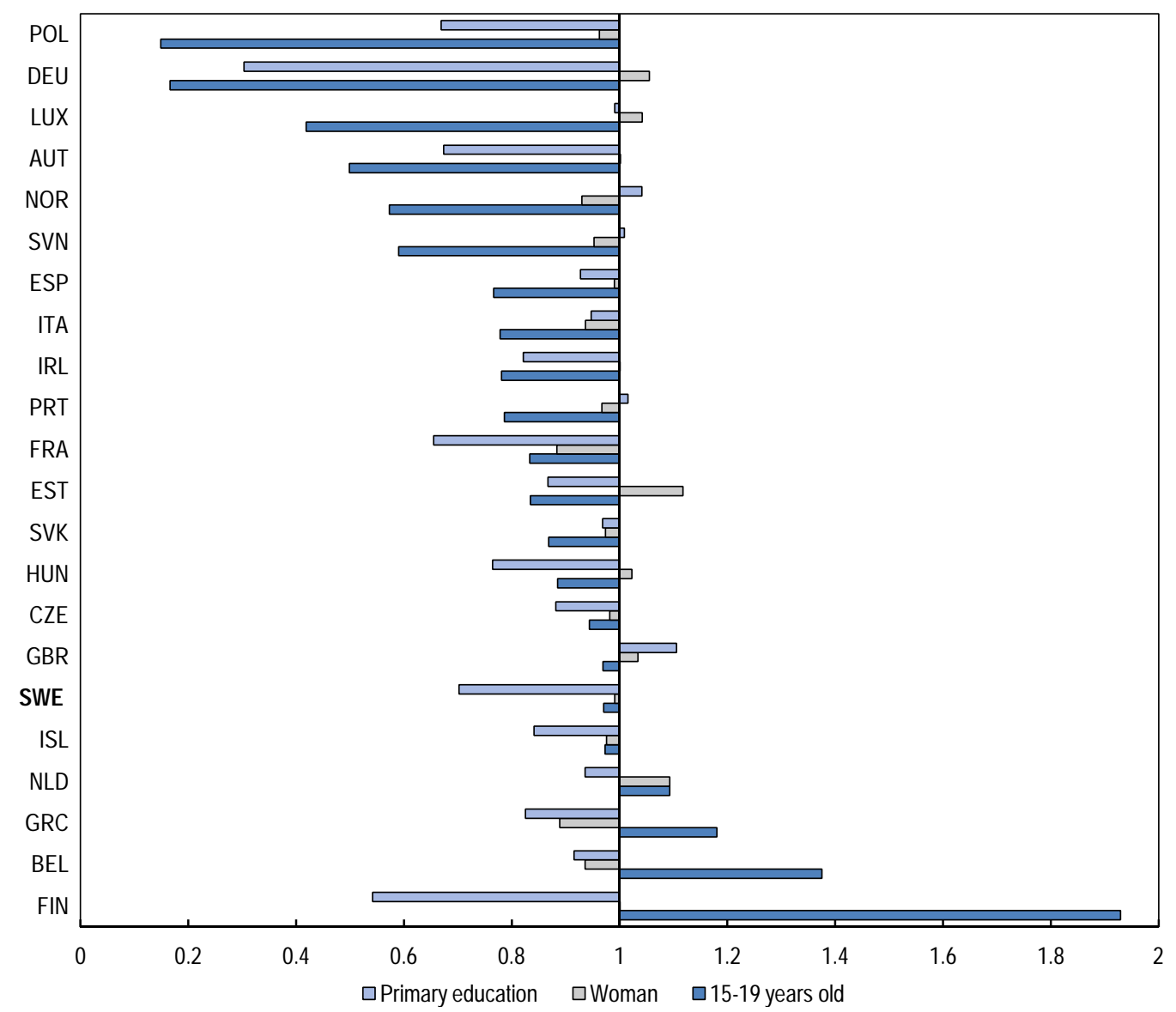

Note: In Sweden for instance, the probability of moving from a temporary to a permanent job for workers who did not graduate from secondary education is $70 \%$ of that for all workers.

Source: SILC Longitudinal Database and OECD calculations.

Options to reform EPL in Sweden have been proposed recently (Cahuc, 2011). The goal should be to achieve some convergence in EPL between temporary and permanent jobs to facilitate the integration of the most fragile groups. There are several ways to achieve convergence, depending on whether a new system is introduced (for instance with a single contract) or the main features of the current system, with two types of contract, are kept. In the latter case, options include the removal of the priority for dismissed workers to be re-hired and of the obligations related to the internal reassignment of employees while having provisions that help to transform temporary jobs into permanent ones. 


\section{Box 3. Explaining the mobility of temporary workers in EU countries and in Sweden}

The probability of moving from a temporary to a permanent job or to unemployment depends inter alia on workers' individual characteristics and on policy settings. A multinomial logit model is estimated to examine how oneyear transitions from a temporary job are influenced by individual characteristics in the European Union and in Sweden (Table 6). Using country fixed effects rather than policy variables such as EPL indicators is advisable as many other factors specific to each country influence transition probabilities.

The cross-country results show that the probability to secure a permanent contract over one year is $33 \%$ higher for people who graduated from secondary education compared to those who did not; that men have $17 \%$ more chances to get a permanent contract; and that 15-19 year-olds and 55-64 year-old temporary workers are respectively $48 \%$ and $15 \%$ less likely to move on to a permanent contract. Probabilities to switch from a temporary to a permanent job are higher for members of households with a higher disposable income. Similar results are obtained for the probability of switching from a temporary job to unemployment, which is higher for the low-educated, youth and lowincome household members.

In Sweden, gender and age do not seem to play an important role in explaining these transitions. The education level is the only significant factor, with a secondary degree raising the probability of getting a permanent contract by $69 \%$ (as against the $33 \%$ EU-wide average). While the coefficients for age and gender are not significant in Sweden, their sign and size are close to the EU-wide ones, which suggests that the small number of observations for the estimate on Sweden may partly explain why these factors fail to be significant.

Table 6. Explaining the transitions from temporary to permanent jobs or unemployment

Multinomial logit regressions, relative-risk ratios of independent variables ${ }^{1}$

Reference labour market state = staying in a temporary contract

\begin{tabular}{|c|c|c|c|c|}
\hline \multirow[b]{3}{*}{ Education } & \multicolumn{2}{|c|}{ All EU countries } & \multicolumn{2}{|c|}{ Sweden } \\
\hline & \multicolumn{2}{|c|}{ Permanent Unemployment } & \multirow{2}{*}{ Permanent } & \multirow[t]{2}{*}{ Unemployment } \\
\hline & & & & \\
\hline Primary education & Ref. & Ref. & Ref. & Ref. \\
\hline Secondary education & $1.33^{* * *}$ & $0.86^{* * *}$ & $1.69^{*}$ & $0.53^{*}$ \\
\hline Tertiary education & $1.22^{* * *}$ & $0.54^{* * *}$ & 1.07 & $0.30^{* * *}$ \\
\hline \multicolumn{5}{|l|}{ Gender and age } \\
\hline Women & Ref. & Ref. & Ref. & Ref. \\
\hline Men & $1.17^{* * *}$ & 0.95 & 1.06 & 1.02 \\
\hline Age $15-19$ & $0.52^{* * *}$ & $0.82^{* *}$ & 0.73 & 1.19 \\
\hline Age $20-24$ & 0.01 & 1.03 & 0.93 & $2.04^{* *}$ \\
\hline Age $25-54$ & Ref. & Ref. & Ref. & Ref. \\
\hline Age 55-64 & $0.85^{* * *}$ & 1.08 & 0.79 & 1.67 \\
\hline \multicolumn{5}{|c|}{ Household disposable income } \\
\hline 1st income quantile & $0.78^{* * *}$ & $2.14^{* * *}$ & 0.75 & $2.32^{* *}$ \\
\hline 2nd income quantile & $0.86^{* * *}$ & $1.28^{\star * *}$ & 0.72 & 0.86 \\
\hline 3rd income quantile & Ref. & Ref. & Ref. & Ref. \\
\hline 4th income quantile & 0.05 & $0.83^{* *}$ & $1.75^{\star *}$ & 1.15 \\
\hline 5th income quantile & $1.12^{* * *}$ & $0.65^{\star * *}$ & 1.41 & 1.21 \\
\hline \multicolumn{5}{|l|}{ Marital status } \\
\hline Married & Ref. & Ref. & Ref. & Ref. \\
\hline Not married & $0.96^{*}$ & $1.46^{\star * *}$ & 0.99 & 0.96 \\
\hline Country fixed effects ${ }^{2}$ & Yes & Yes & & \\
\hline Time dummies ${ }^{3}$ & Yes & Yes & Yes & Yes \\
\hline Number of observations & 45223 & 45223 & 724 & 724 \\
\hline
\end{tabular}

Note: ${ }^{* * *},{ }^{* *}$ and ${ }^{*}$ indicate that the coefficients are statistically significant at the $1 \%, 5 \%$ and $10 \%$ levels.

1. Change in the predicted probability of making the indicated transition which is associated with an increase from 0 to 1 of the indicated dummy variable, when all other variables are set at their sample means.

2. Countries: Austria, Belgium, the Czech Republic, Germany, Estonia, Spain, Finland, France, Greece, Hungary, Ireland, Iceland, Italy, Luxembourg, Netherlands, Norway, Poland, Portugal, Sweden, Slovenia, the Slovak Republic and the United Kingdom.

3. All the available years (2003-09) from the SILC longitudinal database have been used.

Source: OECD estimates based on SILC data. 


\section{Support to the unemployed provides uneven social protection and incentives to take a job}

The share of the unemployed covered by unemployment insurance (UI) has been shrinking over time, partly because the eligibility criteria concerning past work have become stricter (Figure 22; Box 4). Furthermore, part-time jobs that only give right to shorter UI benefits have become more widespread and the composition of unemployment has changed, with a larger share of the unemployed with no or limited labour market experience, such as youth, workers with a low level of education and some newly-arrived immigrants. As a result, an increasing share of the unemployed is covered by social assistance instead of UI.

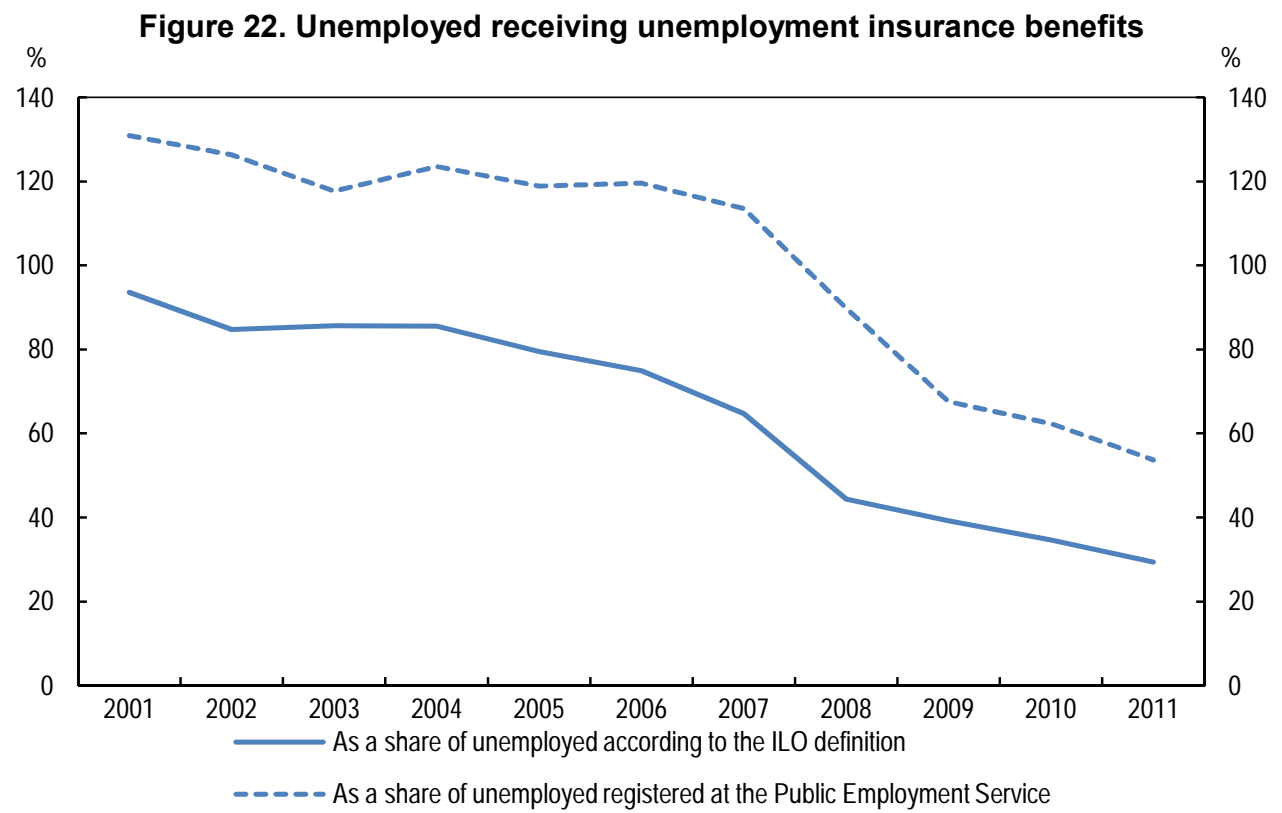

Note: Yearly average. Before 2008, more unemployed were covered by receiving UI benefits than registered at the PES, explaining why the share was above $100 \%$.

Source: Statistics Sweden, Swedish Public Employment Service.

The fact that a significant share of the unemployed does not receive UI benefits but municipal welfare benefits instead creates a number of problems:

- The unemployed on social assistance tend to receive less income than those on UI, although this depends on various parameters, and are therefore more exposed to the risk of poverty.

- Welfare benefits are means tested, implying a high average effective tax rate that discourages the unemployed from taking a job, and therefore, leads to inactivity and poverty traps (Figure 23). The measure included in the Budget Bill for 2013 (Annex 1) to make is easier to cumulate labour income and social assistance will mitigate this problem. Nonetheless, social assistance being a last resort based on household income, it is not always possible to introduce some financial sanctions if the unemployed do not fulfil some of their obligations, which weakens their jobsearch incentives.

- Municipalities tend to be less efficient at monitoring job search and assisting the unemployed than the PES, although efficiency varies between municipalities (Dahlberg et al., 2009). Accordingly, those who are further away from the labour market tend to get less efficient support (see below). 
- The unemployed receiving social assistance have to register both at the PES and with the municipal services, causing some efficiency losses.

\section{Box 4. Unemployment insurance in Sweden}

Swedish public unemployment insurance (UI) is regulated and subsidised by the state, but administered by the UI funds. Some but not all UI funds are closely linked to labour unions. Since 2007, the state subsidy amounts to approximately $70 \%$ (Anxo and Ericson, 2011). The remaining part of the financing comes from worker fees paid to the Ul funds. Fees are fixed by the government and differentiated according to the sectoral unemployment rate, in order to get unions to internalise the unemployment cost of overly high wages.

The UI has two components: a basic allowance and an income-related benefit. The basic allowance amounts to SEK 320 (around $€ 40$ ) per day in 2012 and the income-related benefit to $80 \%$ of the past wage during the first 200 days of unemployment and $70 \%$ thereafter, with a ceiling at SEK 680 . The basic allowance is available to those who are over 20 years old. To qualify for an income-related benefit, the unemployed person must have been a member of a $\mathrm{UI}$ fund for at least 12 months. For both types of $\mathrm{UI}$ benefit, the maximum entitlement period is 300 days and 450 days for parents with children. There is a seven-day waiting period for all the unemployed. In addition, workers may contribute to a private insurance.

The eligibility criteria are the same for the two components. The unemployed need to have worked for a certain time, to look for a job and to be registered at the Public Employment Service (PES). Part-time workers are entitled to a shorter period of UI benefits. During the first 300 days, the unemployed may be oriented towards an active labour market policy (ALMP) programme. After 300 days, the unemployed is eligible for activity support corresponding to $65 \%$ of the income loss provided she or he participates in an ALMP programme (within the so-called "Job and Development Guarantee"). Activity support is fully financed by the government.

Those aged less than 25 face a different benefit structure. Recipients of the income-related benefit see it decline faster. Those who are not entitled to the income-related benefit or to the basic allowance and who are over 20 and have completed upper secondary education receive an allowance of SEK 140 per day (corresponding to the study allowance paid to those who are in tertiary education). The 18-20 year-olds who have not completed upper secondary education receive SEK 48 per day, corresponding to the study allowance for students in upper secondary education. After 100 days, youth have to participate in the "job guarantee for youth" programme to receive these benefits. the PES.

The PES is in charge of monitoring job search efforts. Furthermore, all unemployed have the right to register at

Those who are not entitled to UI receive social assistance, which is provided by municipalities. Municipalities also run some ALMP programmes. Those who have received social assistance for 14 months and, during this time period, have been unemployed and registered at the PES are offered the option to participate in the Job and Development Guarantee and to receive activity support.

To ensure that a larger share of the unemployed get UI benefits instead of welfare benefits, work conditions should be eased. With enlarged UI coverage, social assistance could target those who are further away from the labour market.

Another issue concerns the optimal level and profile of unemployment benefits. According to theoretical models, the benefit should decline over time to provide optimal job-search incentives. Furthermore, similar models show that indexation of unemployment benefits on previous earnings tends to foster wage moderation and thus leads to higher employment (Heer and Morgenstern, 2005). This is because, when wages are bargained, firms take into consideration that the utility of the union, which depends on the utility of its employed and non-employed workers, will be less affected by a lower wage when the indexation of unemployment benefits on previous earnings is larger. Against this backdrop, the current system suffers from several problems:

- Only the unemployed with an income-related benefit under the ceiling have their benefit decreasing with time and linked to previous wages. For those who are at the ceiling, or receive the basic allowance, or receive welfare benefits, the profile is flat and the level of benefit is not linked to previous income. In 2009 , only $13 \%$ of the unemployed had a compensation that was declining with time (Swedish Fiscal Policy Council, 2011). 
- Having some unemployed receiving an income-related benefit and others only the basic allowance creates inequalities between these two groups as the level of the benefit is different, all the more so as the UI system, including the income-related part, is mainly financed by the government, i.e. by taxpayers.

- The unemployed entitled to the basic allowance are more likely to receive other means-tested welfare benefits and therefore, to face higher average effective tax rates and lower incentives to take a job.

Figure 23. Inactivity and unemployment traps in $\mathbf{2 0 1 0}$
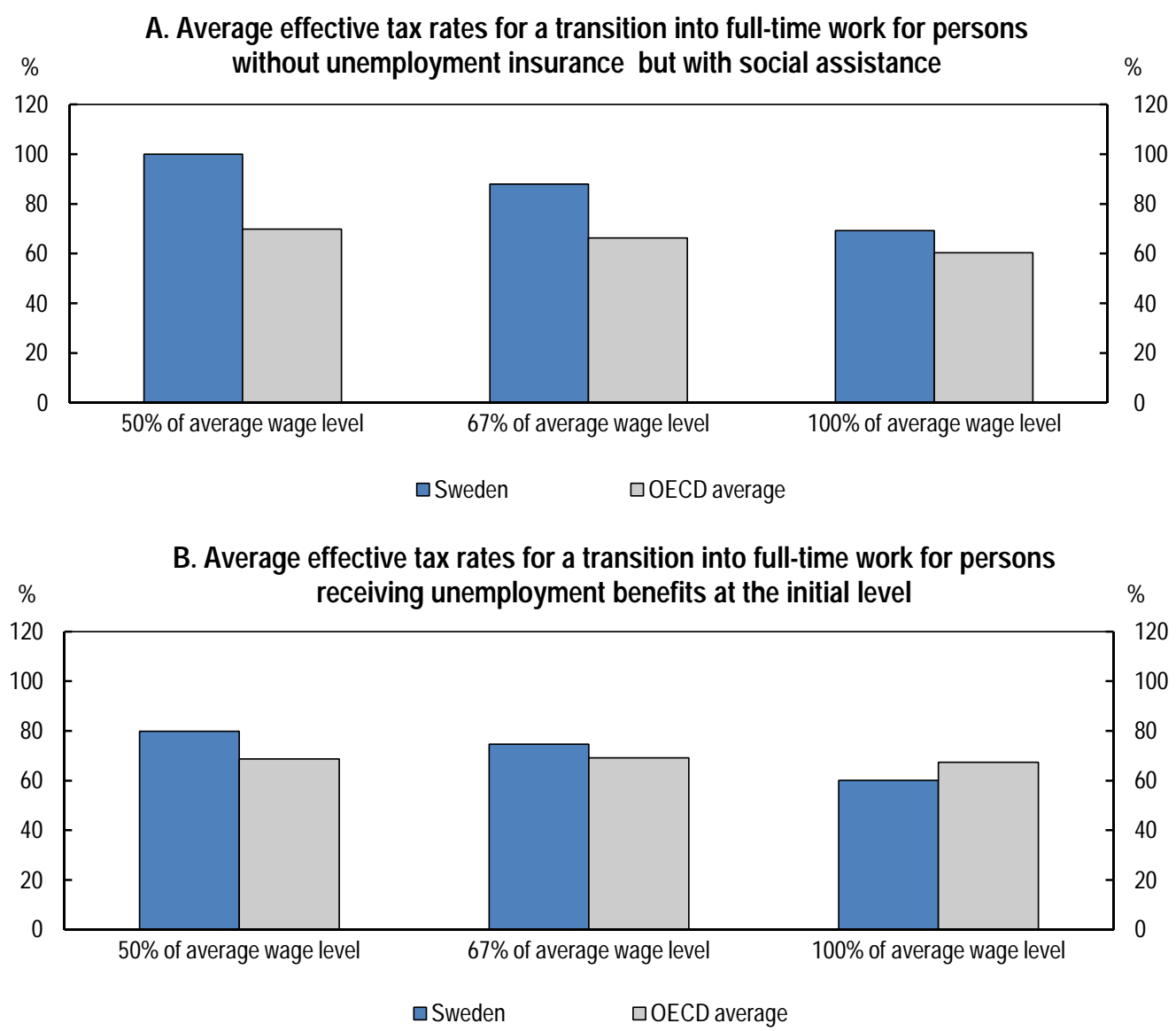

Source: OECD, Tax-Benefit Models.

To enhance job-search incentives and make them more uniform across the unemployed, most workers should be covered by a benefit that declines with time. The benefit needs to be sufficiently generous at the beginning of the unemployment spell so that it can diminish over time without pushing recipients into poverty. One option would be to have all eligible unemployed receive an income-related benefit. In most OECD countries, the UI benefit is linked to previous income as a flat rate needs to be very low to provide job incentives to low-paid workers, which tends to increase the risk of poverty.

Extending the coverage of UI and changing the structure of the benefit would justify broadening its financing base. In the current set-up, UI fund member fees are linked to the unemployment rate in the sector and are partly state-financed. In theory, this should encourage UI funds to monitor their members' eligibility for UI benefits, and employer and employee confederations to internalise the impact of their wage negotiations on unemployment as they have close links with these funds. However, in practice, the 
system does not fully deliver these effects (Swedish Fiscal Policy Council, 2011). This is mainly because unions are in fact in charge of paying UI benefits for only a limited number of unemployed who are likely to be relatively close to the labour market. The fact that UI funds stop to pay benefits after 300 days of unemployment (at which point the state takes over) entails perverse incentives for wage formation. Furthermore, the link between UI funds and unions is actually not that tight. Therefore, it would make sense to broaden financing and to make contributions to UI mandatory. At a minimum, the distinction between the unemployment benefit and activity benefit should be removed and both benefits should be financed by the same institution. In that case, and if contributing to UI is not made mandatory, the system of differentiated fees could be kept as the extension in the coverage of UI would make it work better.

Changes to the financing of the UI system could have implications for the membership of trade unions as some UI funds and trade unions are closely linked (Box 4). While there is no assessment of the impact of such an arrangement on labour market performance, recent research has explained the strong involvement of labour unions in Scandinavian countries by the high trustworthiness and civicness of citizens, which has allowed labour relations to develop without the need for state regulation (Aghion et al., 2011). The impact of making contributions to UI mandatory on union membership is unclear and would depend on the way this would be implemented. In any event, contributions to an UI fund and to a trade union do not have to be linked. Indeed, the option of remaining a union member without contributing to an UI fund has been used more and more since 2007 as fees were increased, somewhat mitigating the fall in trade union density (Kjellberg, 2009).

\section{Job-search monitoring and the efficiency of ALMPs can be strengthened further}

The increase in labour supply and in the heterogeneity of the unemployed has generated new challenges for the PES, which has tried to adapt. Its services are now more customised to specific individual needs. Its resources for placement and related services have been tripled since 2004 and its overall resources are high from an international perspective (Figure 24). In 2012, almost $80 \%$ of the PES staff was working directly with clients and more than $10 \%$ were specialists, including psychologists. The PES has introduced various specific programmes for targeted groups such as immigrant women, young unemployed with mental health problems and groups suffering from discrimination. One example is the "Youth in" project for youth belonging to the NEET group (Box 5). The PES website is translated into various languages and thus easily accessible to most newly arrived immigrants.

\section{Box 5. Targeting youth risking long-lasting social exclusion}

The PES and the Stockholm Youth Centre (Fryshuset) are piloting a project to reach and motivate youth who suffer from social exclusion. In itself, Fryshuset is in fact more than a youth centre as it has schools that combine basic education with sports and culture and various social projects (for youth from families with addiction problems, or to combat violence and vandalism, the formation of destructive subcultures, etc.). More precisely, the joint PES and Fryshuset programme (financed by the European Social Fund) targets $16-24$ year-olds who are not studying, working nor involved in any other recognised occupation, and who are not in contact with the PES or with social services. The goals of the programme are that by the end of the project: $50 \%$ of the participants will have tried at least two to four short-term jobs, $30 \%$ will have started a job or studies and $80 \%$ will feel they have strengthened their position in the labour market and their self-esteem. The programme concerns Stockholm but will be implemented in other cities if successful.

The method is based on individual interviews to assess the participant's formal and informal knowledge as well as her/his situation in terms of health, accommodation, family, education, work and contacts with the government. Then, a series of activities is proposed to the participant including short-term jobs, mentoring, internships, and workplace visits. The team in charge of the programme includes staff from the PES, social services and the education system, social workers and psychologists.

The first phase of the project included 60 participants, with $80 \%$ of them having disabilities and mental health problems. The outcomes are promising: $32 \%$ of the participants were employed at the end of the project, $8 \%$ had returned to education and $40 \%$ had held short-term jobs. 
Figure 24. Public expenditure on active labour market policies in OECD countries

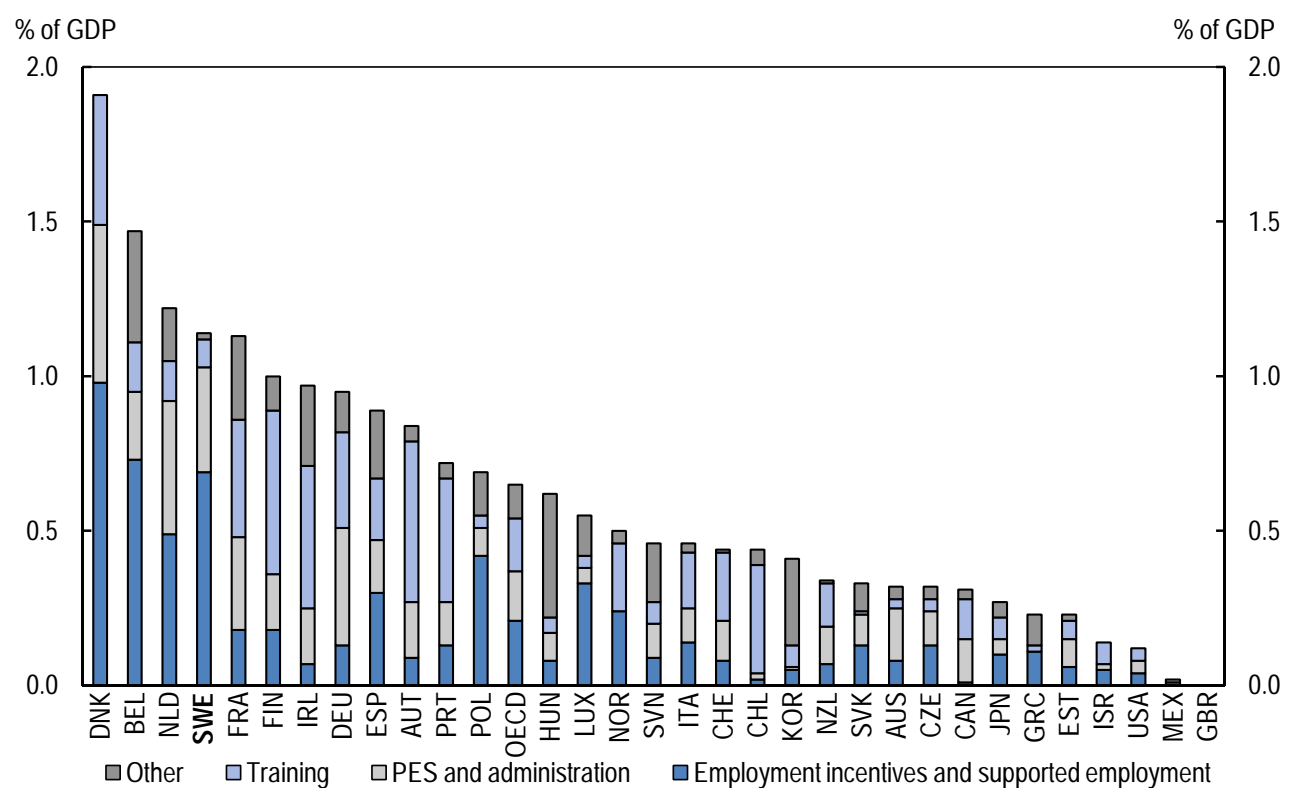

Source: OECD, Employment Outlook.

Since 2008, the PES has become more involved in the rehabilitation of people on sick-leave or with disabilities. However, that the payment of related benefits has remained under the Social Insurance Agency (SIA) while the PES is in charge of job-search support has created inefficiencies. For instance, not many actions are initiated in the earlier phase of sickness absence, even though this can be very important for unemployed with mental health problems (OECD, 2012g). Co-operation between the SIA and the PES will have to continue to be strengthened further. In addition, the rehabilitation chain has been less efficient for persons with mental disorders who stay on sickness benefit much longer than other recipients of these benefits. Efforts to improve the efficiency of the rehabilitation chain should continue.

The PES has also been granted more responsibility concerning the integration of immigrants. A special labour market programme ("Step-In Jobs") was introduced in 2007 to promote the integration of newly arrived immigrants into the labour market. It includes a wage subsidy of $75 \%$ of the gross wage. In 2010, an Introduction Act entered into force with the aim of formalising the various forms of support proposed to newly-arrived immigrants through the family and asylum channels. It includes Swedish courses, civic orientation and employment preparation activities. The PES is in charge of coordinating activities and providing monitoring data that will be used for an assessment by researchers in 2015 .

This enlargement of the responsibilities of the PES should continue and the PES should be in charge of job search help for all the unemployed. In parallel, the PES should have the full capacities to monitor job-search and sanction insufficient efforts. According to an OECD indicator, the overall strictness of eligibility criteria for the unemployment benefit is the lowest in the OECD (Figure 25). While this indicator only captures the strictness of rules as they are outlined in legislation rather than how they are enforced and is subject to other limitations, it does highlight some of the specificities of the Swedish system. According to the indicator, entitlement conditions tend to be relatively strict, consistent with the fall in the number of unemployed covered by UI. By contrast, monitoring is not stringent at all, Sweden being one of the rare OECD countries where the unemployment benefit recipient does not need to provide evidence of job-search activity. 
Figure 25. Overall strictness of eligibility criteria for unemployment benefit

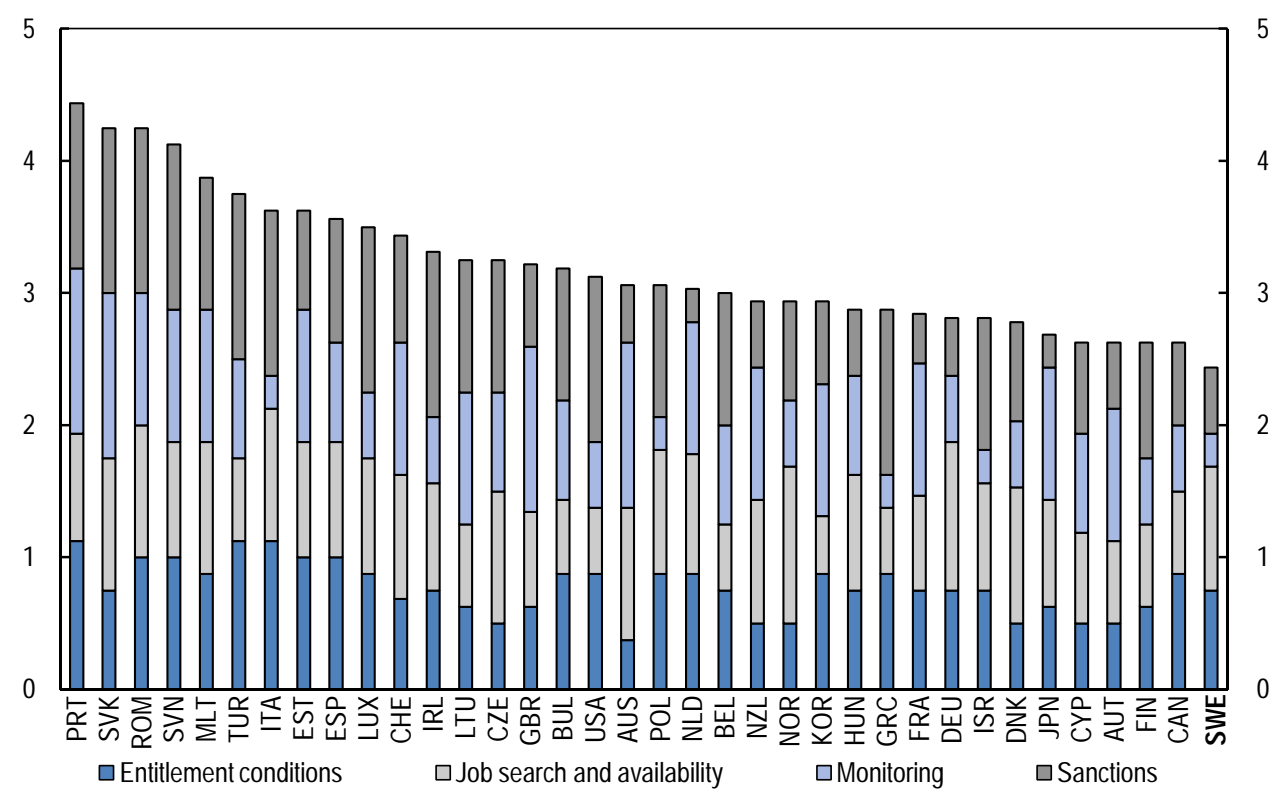

Note. The composite indicator of the strictness of eligibility criteria is based on information on entitlement conditions (employment and/or contribution requirements to gain access to benefits and sanctions for voluntary unemployment), job-search requirements (availability requirements during ALMPs and suitable work criteria), monitoring of job-search effort and sanctions for refusing a job offer or ALMP placement. Countries are allocated a score for each item from one (least strict) to five (most strict) and these data are used to compile the composite indicator. For most items, data reflect eligibility criteria in place in 2011.

Source: Venn, D. (2012), "Eligibility Criteria for Unemployment Benefits: Quantitative Indicators for OECD and EU Countries", OECD Social, Employment and Migration Working Papers, No. 131.

Measures in the Budget Bill for 2013 (Annex 1) aiming at harmonising sanctions across categories of unemployed and introducing milder and more gradual, and hence, easier to implement, sanctions are welcome. In particular, the PES should have the right to sanction those who receive the activity support, which is given to the long-term unemployed once UI benefits have expired, as proposed in the Budget Bill. Welfare benefits are harder to sanction because they are last-resort benefits and tend to be very low. Furthermore, even if recipients of welfare benefits have to formally register with the PES, they may be monitored by municipalities with weaker job-search obligations. Extending the coverage of UI benefits as proposed in the previous section would allow the PES to be able to monitor and sanction a wider range of the unemployed. The proposal to shift the burden of proof of job-search activity onto the unemployed is also welcome. However, it will be important to develop an efficient system of control of job-search activity that does not rely solely on jobseekers' declarations.

Studies of the efficiency of Swedish ALMPs tend to deliver mixed results, suggesting that they can be improved further (Forslund et al., 2011; SOU, 2010; Forslund and Nordström Skans, 2006). Specifically:

- Swedish ALMPs have indirect effects as the activity requirement to receive financial support raises the incentives to look for a job and accept it before having been placed in these programmes (pre-programme effect). Hence, enrolment in the PES should aim at helping jobseekers with good labour market prospects to increase job-search effort but these jobseekers should not be offered the most ambitious programmes, which should target those with poor labour market prospects (SOU, 2010).

- Job subsidies are widely used in Sweden, but training programmes are less developed (OECD, 2011d; Figure 24). Job subsidies for large groups of unemployed help some of them to find a job but have generated displacement effects as a significant share of these jobs would have been 
created anyway. Hence, a key issue is to ensure that these subsidies benefit those most in need. The efforts of the PES to actively build contacts with employers, including large firms, so as to "place" the unemployed in exchange for some form of support, can help make up for the lack of contacts of some groups of unemployed but may create displacement effects. The Budget Bill for 2013 includes a doubling of the subsidy under the New Start Jobs programme for young unemployed (Annex 1). While raising the subsidy is estimated to reduce the time spent in unemployment, this programme is expected to lead to displacement effects (Liljeberg et al., 2012). Therefore, it would be important to assess the effect of the profiling tool used at the beginning of the unemployment spell to identify the unemployed who will receive active job-search help.

- An open question is how to help those who are furthest from the labour market to become durably employed. The Swedish experience with placing the unemployed on positions with no payment from employers, as part of the third phase of the job and development guarantee, has not been successful as these persons seem to retain no benefit from these experiences. The literature suggests that lock-in effects can be sizeable with a compulsory programme targeting a large group, as is the case with the job guarantee. Recent studies call for more individualised service provision that would, for instance, include intensified matching efforts and subsidies targeted to small groups of workers (Sabel, 2012).

\section{The education system has a key role to play}

Education has a key role to play to ensure that new potential entrants have the necessary skills. The risk of becoming unemployed was much higher for those who have not completed upper secondary education in 2010 (Table 3).

Enrolment rates for early childhood and primary education are high in Sweden, but graduation rates for upper secondary education are below the OECD average. Furthermore, learning outcomes are below the OECD average in science and close to average in mathematics even though education spending per student ranks among the highest across OECD countries (OECD, 2010c). PISA results indicate that disadvantaged students are more at risk of being low performers in Sweden than in a number of other countries. For instance, learning outcomes at age 15 for the foreign-born are much lower than for the natives, with the gap wider than in other countries with similar shares of foreign-born students (Figure 26). Compared with other OECD countries, drop-out rates are lower in Sweden despite the prominence of the issue in the public debate, but they are rising. This evidence suggests that weaknesses in the education system may contribute to the relatively weak labour market performance of low-educated youth.

In 1992, Sweden implemented a major reform of compulsory education by introducing a system of school choice. The share of students enrolled in an independent lower secondary school rose from below $1 \%$ in 1992 to $12.5 \%$ in 2011-12. Independent schools receive public funding on the same basis as municipal schools in the same area. Empirical studies find that competition between schools and the increase in the share of students enrolled in independent schools have improved education outcomes (Bergström and Sandström, 2001; Björklund et al., 2004). This concerns average performance at the end of compulsory school, but also in tertiary education (Böhlmark and Lindahl, 2012). However, students from wealthy and highly educated families have benefited more from the reforms than students with disadvantaged backgrounds (Böhlmark and Lindahl, 2007). There are signs that segregation has increased, as have differences in resources between schools. Higher students-per-teacher ratios also seem harmful for immigrant students. Intergenerational mobility, which has been relatively high in the past, may decline over time as a result of rising inequalities in the education system (Björklund et al., 2011). 
Figure 26. Gap in learning outcomes at age 15 between natives and foreign-born

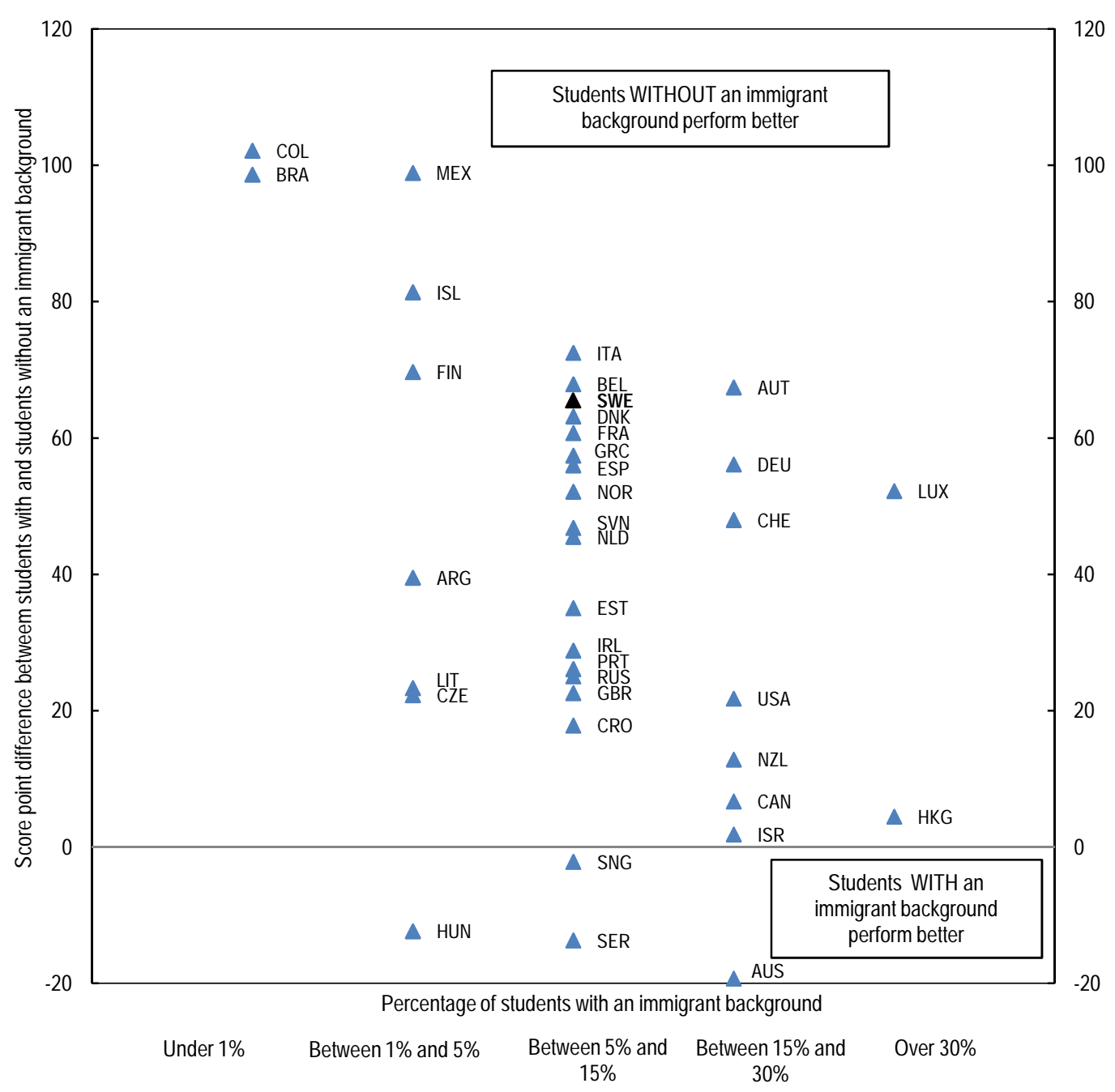

Note: Countries are classified on the horizontal axis according to the share of students with an immigrant background in all students. The vertical axis indicates differences in reading performance according to PISA results in 2009 between students with an immigrant background and native students. A positive gap shows weaker performance for students with an immigrant background than for the natives and vice versa. In Sweden, for instance, between $5 \%$ and $15 \%$ of students have an immigrant background, and their learning outcomes are around $70 \%$ of those of the natives.

Source: OECD Programme for International Student Assessment (PISA).

A number of further reforms have taken place in recent years in compulsory education, not least to improve weaker students' performance. A new curriculum was introduced in 2008 . The overall framework of education policies was reviewed and the major goals of the educational system were restated in the 2011 new "Education Act". A reform of upper secondary education was introduced in 2011 with the aim of limiting drop-outs and easing transition to tertiary education and the labour market. The 2011 Budget also included measures to improve teacher quality. These reforms go in the right direction but may take time to deliver benefits and should therefore be monitored closely.

For many youth, combining study and work is more efficient to ease the transition from school to work than the traditional model of "study first, then work" (OECD, 2010a). On-the-job training helps students acquire the skills required by employers. In addition, new entrants should continue to learn on the job and, if necessary, be prepared to resume a more academic education to reinforce their employability, 
particularly when they have low skills. In this area, the Swedish system lacks flexibility and co-operation between schools on the one hand, and employer and labour market institutions on the other hand. In particular, vocational education and training (VET) in Sweden has long been considered as a preparation for the labour market rather than for a job (OECD, 2008).

As part of the 2011 reform of upper secondary education, VET education was reviewed and efforts have been made to target it better to labour market needs, while the evaluation and assessment framework was strengthened. Some of these measures are in line with OECD recommendations (Box 6). However, as VET education now focuses more on specific subjects, students no longer complete the same core curriculum as those in academic upper secondary programmes and are not automatically eligible to tertiary education anymore. This may stigmatise VET education as being for the less able (Kuczera et al., 2008). A pilot project aiming at developing apprenticeships in VET started in 2008 and was made permanent in 2011 (Swedish National Agency for Education, 2012). The Budget Bill for 2013 includes welcome measures to develop further apprenticeship programmes through higher subsidies for employers and training for supervisors and to temporarily increase the number of training places (Annex 1).

International experience with VET shows that several elements underpin successful apprenticeship systems (OECD, 2010d). There should be incentives to sustain the commitment of both students and firms, calling for subsidies or tax breaks and efforts to develop these programmes in various sectors - not only in building and construction, as is mainly the case in Sweden, but also in rapidly expanding sectors. Close links between schools and local employers will contribute to efficient career guidance and to preparing apprentices' supervisors in companies. Strong institutions to engage employers, unions and students, and to carefully monitor these programmes are also important. The National Agency for Education has appropriately been given more responsibilities in the areas of VET but it should also work closely with other institutions including the PES. The Swedish social partners also have a major role to play.

\section{Box 6. Improving vocational education and training in Sweden}

The OECD review on vocational education and training in Sweden (Kuczera et al., 2008) made the following recommendations:

- Maintain the same core curriculum as those in academic upper secondary programmes.

- Introduce a stronger mechanism through which the social partners can convey labour market requirements to VET providers. To this end a National Commission for VET should be established, composed of different government ministries and the social partners.

- Information on the labour market outcomes of VET should be published on a school and programme basis. The National Register should be fully exploited, and possibly supplemented by regular surveys of recent leavers.

- $\quad$ The 15-week work placement that is part of upper secondary VET should be subject to quality control and made mandatory for all upper secondary VET programmes. Only VET programmes capable of attracting work placements should be provided.

- $\quad$ Develop an apprenticeship system to complement school-based VET on the grounds of both cost and quality. It should be developed jointly by the government and the social partners and take full account of international experience. 


\section{Access to health care could be made more equal}

Health problems can impede labour market integration and lead to exclusion and poverty. A well-performing healthcare system is important to maintain those with health problems in the labour market. At the same time, equal access is needed so that the healthcare system does not add to inequality.

In terms of health status, Sweden tends to outperform similar countries and the OECD average (Table 7). These good results can be ascribed to relatively high spending on health (mainly public) and an efficient system (Joumard et al., 2010). The health care system is decentralised and a set of indicators covering medical results, patient experience, availability of care and costs allows comparisons of local performance (National Board of Health and Welfare, 2008a).

Equal access to care is one of the main goals of the Swedish health care system. In this area, Sweden's outcomes are mixed. On the one hand, unmet needs for care and for medical examination due to cost, and exposure to large out-of-pocket spending are relatively low for lower incomes (OECD, 2011e). On the other hand, access to doctors and dentists is more unequal in Sweden than in many other OECD countries (van Doorslaer et al., 2006; OECD, 2011e). Swedish studies confirm that there are some inequalities in access to medical care (Anell et al., 2012). In 2001, the National Board of Health and Welfare reported a greater number of health care visits among individuals with higher education, even though health needs were more severe for less-educated individuals (National Board of Health and Welfare, 2001). In 2006, the same institution indicated that inequity across groups based on educational background had worsened (National Board of Health and Welfare, 2007). Lower access to health for immigrants coming through the asylum channel is also a source of concern (National Board of Health and Welfare, 2008b).

Table 7. Health status indicators

\begin{tabular}{|c|c|c|c|c|c|c|c|}
\hline \multicolumn{8}{|c|}{0} \\
\hline & \multirow{2}{*}{$\begin{array}{l}\text { Life } \\
\text { expectancy } \\
\text { at birth }^{1}\end{array}$} & \multirow{2}{*}{$\begin{array}{c}\text { Life } \\
\text { expectancy } \\
\text { at } 65^{1} \\
\text { Women }\end{array}$} & \multirow{2}{*}{$\begin{array}{l}\text { Life } \\
\text { expectancy } \\
\text { at } 65^{1} \\
\text { Men }\end{array}$} & \multirow{2}{*}{$\begin{array}{c}\text { Infant } \\
\text { mortality }^{2}\end{array}$} & \multicolumn{3}{|c|}{ In-hospital case-fatality rates ${ }^{3}$} \\
\hline & & & & & $\begin{array}{c}\text { Acute } \\
\text { myocardial } \\
\text { infarction }\end{array}$ & $\begin{array}{l}\text { Ischemic } \\
\text { stroke }\end{array}$ & $\begin{array}{c}\text { Hemorragic } \\
\text { stroke }\end{array}$ \\
\hline Sweden & 81.5 & 21.1 & 18.2 & 2.5 & 2.9 & 3.9 & 12.8 \\
\hline Denmark & 79.3 & 19.7 & 17.0 & 3.4 & 2.3 & 2.6 & 16.4 \\
\hline Finland & 80.2 & 21.5 & 17.5 & 2.3 & 4.8 & 2.8 & 6.5 \\
\hline France & 81.3 & 22.5 & 18.2 & 3.6 & & & \\
\hline Germany & 80.5 & 20.9 & 17.8 & 3.4 & & 4.0 & 13.8 \\
\hline Norway & 81.2 & 21.2 & 18.0 & 2.8 & 2.5 & 2.8 & 11.6 \\
\hline OECD average & 79.7 & 20.5 & 17.2 & 4.1 & 4.3 & 5.2 & 19.0 \\
\hline Best performing country & 83.0 & 23.9 & 19.0 & 2.2 & 2.3 & 1.8 & 6.5 \\
\hline Worst performing country & 74.3 & 16.1 & 13.8 & 14.1 & 6.6 & 17.6 & 38.6 \\
\hline
\end{tabular}

1. Years.

2. Per 1000 births.

3. Age-sex standardised rates within 30 days after admissions, 2009 or nearest year.

Source: OECD (2012), Health at a Glance 2012, Paris.

Various reasons may explain unequal access (OECD, 2005; Anell et al., 2012). Access differs geographically depending on the density of the population and the distance to the point of service. While specialised services are easy to access in large cities, this can be a problem in rural areas with shortages of physicians. Geographical inequalities can reflect inequalities in terms of socio-economic background insofar as low incomes tend to be concentrated in some areas. Another reason could be the user charges that apply for all types of health services. While co-payments are capped, they may still restrict access for 
some vulnerable groups. Besides, user charges for dental care can be high for groups with costly treatments such as older people. Finally, waiting times are relatively long for specialists, which may contribute to inequalities in access to health care (OECD, 2011e).

Since 2007, a series of reforms have been launched, county by county, to introduce choice and privatise primary care providers. In 2010, the Health Care Act was changed to account for these new developments, and now stipulates the freedom of choice of primary care provider for the population and the freedom of establishment for providers accredited by the local county councils. The purpose of these reforms was to develop primary care and improve its efficiency, notably in terms of access (OECD, 2005).

Early evaluations of the introduction of choice and competition in primary care suggest that access has improved in some areas (Glenngård et al., 2011; Anell et al., 2012). Between 2007 and mid-2010, the number of primary care centres increased by $23 \%$. An evaluation of the reform in Stockholm indicates that the use of primary care has increased for all age groups but more so for patients with multiple chronic illnesses and in low-income areas. Productivity is found to vary considerably across providers but there is no significant difference between public and private providers. Further evaluations are required to assess the overall impact of the reform. Payment systems differ between counties, so that the impact of the reform can also differ. Recent debates surrounding large private providers of elderly care making big profits while unduly lowering the quality of services suggest that the impact of the reform in terms of prices and quality of service, equality in access, and public finances needs to be closely monitored. The creation of a new independent health care supervisory authority, as announced in the Budget Bill for 2013, could help ensure a successful outcome of the reform.

\section{Women's employment opportunities could be improved further}

Various factors can impede women's rise to leadership and make them choose or be trapped into relatively low paid positions and in jobs with limited career progression. General norms and cultural practices, lack of role models and of flexible work conditions are estimated to be among the most important barriers to women's leadership (OECD, 2012c). The government should continue to help address cultural barriers and stereotypes about the role of women in society and business through collaboration with business, schools or the media. These can include reports and statistics about women in business as well as support to awards for women in business and to good management practices.

Family policies improve gender equality by raising female labour force participation, but may not be fully effective in ensuring career prospects (Hakim, 2000; Halldén, 2009). Child care mainly takes the form of centre-based care. While this may be explained by child development objectives, centre-based care may provide less flexibility to households than or may require to be complemented by some other forms of child-care. Relatively high wages at the bottom of the wage distribution make it costly to hire professional household service providers (Albrecht et al., 2003). In Sweden, both men and women spend more time on household services than in the United States since their high cost and social norms against buying household services encourage people to perform their own household tasks rather than relying on market provision. Policies to improve wage flexibility at the lower end of the wage distribution, as proposed earlier in this paper, would lower the cost of in-house child-care. In 2007, a tax deduction for up to $50 \%$ of expenses for domestic household-related services was introduced, mainly to reduce the extent of informal economic activity. The fact that the tax deduction covers various domestic services including house renovation makes it hard to assess its impact on female employment outcomes. The impact of the tax deduction on female employment outcomes should be monitored.

The differences in the use of flexible working-time arrangements and parental leave between men and women might also contribute to persistent divergences in their career profiles (OECD, 2011f). Parental leaves are relatively long in Sweden, with women taking most of them. Empirical analysis shows that women taking 16 months leave have been less likely to see a progress in their careers once back on the job again (Evertsson and Duvander, 2010). Parental leaves have been changed on a number of occasions to 
achieve a more gender-equal division of these leaves (Duvander and Johansson, 2012). However, in 2010, women were still taking almost $80 \%$ of them. Efforts should continue to encourage both parents to use parental leave to improve gender equality.

\section{Conclusions}

Sweden is an egalitarian country but inequalities are rising and some groups tend to struggle more to integrate the labour market. To some extent, this reflects that the benefits of labour market and social policy reforms take time to fully emerge, especially as regards potential employment. This is especially the case for education system reform. However, the rise in inequalities and lasting unemployment problem may also come from the fact that reforms have mainly addressed the supply side of the labour market while less has been done on the demand side. Past unemployment insurance reforms have addressed some issues but have created other problems such as a fall in coverage and differences in incentives and support between groups of unemployed.

To achieve inclusive growth in future years, it is important to continue with structural reforms. A comprehensive strategy is required, with the main recommendations summarised in Box 7. Structural reforms are needed to boost labour demand with the EITC at least partly offsetting any negative impact on individual income. The asymmetry in EPL between temporary and permanent contracts needs to be reduced. UI could be reformed to make it more uniform between groups with stronger requirements for the unemployed. Reforms of the education system need to continue to ease the transition from education to employment and to raise the productivity of new entrants. The effects of recent reforms of the health system would have to be closely monitored to ensure that access does not become more unequal.

\section{Box 7. Key labour market and social policy recommendations for growth to become more inclusive}

- $\quad$ Reduce the gap between the labour cost and productivity of workers at risk. The government should continue talks with social partners to develop employment contracts that improve employment opportunities for such workers. Studies on the impact of minimum wages on employment should be commissioned and published regularly.

- $\quad$ Reduce the gap in job protection legislation between temporary and permanent contracts. This can be achieved in various ways. Under the current system, job protection on permanent contracts needs to be eased.

- $\quad$ Consider extending the coverage of unemployment insurance by easing the entitlement conditions in terms of duration of past work and moving to a system with mandatory contribution to unemployment insurance.

- Continue to strengthen the obligations of the unemployed and the Public Employment Service's power of sanction. Make sure that all unemployed are actually covered by the Public Employment Service regardless of the type of support they receive. Implement plans to shift the burden of proof of job-search activity to the unemployed and develop an efficient control system of job-search.

- Improve the use of profiling to identify individuals at risk of becoming long-term unemployed. Continue efforts to develop small-scale individualised services. Improve co-operation between the PES, the Social Insurance Agency and the education system.

- Develop further apprenticeship programmes and work placement in vocational education.

- Assess the impact of recent reforms of primary health care in terms of quality, equality of access and cost.

- Continue efforts to reduce the differences in the use of parental leave between men and women. 


\section{Bibliography}

Aghion, P., Y. Algan and P. Cahuc (2011), "Civil Society and the State: The Interplay Between Cooperation and Minimum Wage Regulation", Journal of the European Economic Association, Vol. 9, No. 1.

Aghion P., E. Caroli and C. Garcia-Penalosa (1999), "Inequality and Economic Growth: The Perspective of the New Growth Theories", Journal of Economic Literature, Vol. 37, No. 4.

Ahlberg, K. and N. Bruun (2005), "Sweden: Transition Through Collective Bargaining", in T. Blanke and E. Rose (eds.), Collective Bargaining Wages in Comparative Perspective: Germany, France, the Netherlands, Sweden and the United Kingdom, Kluwer Law International, The Hague.

Albrecht, J., A. Bjorklund and S. Vroman (2003), “Is There a Glass Ceiling in Sweden?”, Journal of Labour Economics, Vol. 21, No. 1.

Anell, A., A. Glenngård and S. Merkur (2012), "Sweden: Health System Review”, Health Systems in Transition, Vol. 14, No. 5, European Observatory on Health Systems and Policies.

Anxo, D. and T. Ericson (2011), "Adapting Unemployment Benefit Systems to the Economic Cycle, 2011Sweden", European Employment Observatory Review.

Arulampalam, W., A. Booth and M. Bryan (2007), "Is There a Glass Ceiling over Europe? Exploring the Gender Pay Gap across the Wage Distribution”, Industrial and Labour Relations Review, No. 60.

Bassanini, A., J. Rasmussen and S. Scarpetta (1999), "The Economic Effects of Employment-Conditional Income Support Schemes for the Low-Paid - an Illustration From a CGE Model Applied to Four OECD Countries", OECD Economics Department Working Papers, No. 224.

Bergström, F. and M. Sandström (2001), Konkurrens bildar skola - en ESOrapport om friskolornas betydelse för de kommunala skolorna, DS 2001:12.

Björklund, A., P.-A. Edin, P. Fredriksson and A. Krueger (2004), "Education, Equality and Efficiency An Analysis of Swedish School Reforms During the 1990s", IFAU Report, No. 1.

Björklund, A., M. Jäntti and J. Roemer (2011), "Equality of Opportunity and the Distribution of Long-Run Income in Sweden", IZA Discussion Papers, No. 5466.

Björklund, A, J. Roine and D. Waldenström (2012), "Intergenerational Top Income Mobility in Sweden: Capitalist Dynasties in the Land of Equal Opportunity?", Journal of Public Economics, Vol. 96, Issues 5-6.

Blau, F. and L.Kahn (2003), "Understanding the International Differences in the Gender Pay Gap", Journal of Labour Economics, No. 21.

Böhlmark, A. and M. Lindahl (2007), "The Impact of School Choice on Pupil Achievement, Segregation and Costs: Swedish Evidence", IZA Discussion Papers, No. 2786.

Böhlmark, A. and M. Lindahl (2012), "Independent Schools and Long-Run Educational Outcomes: Evidence from Sweden's Large Scale Voucher Reform", IZA Discussion Papers, No. 6683.

Bonesmo Fredriksen, K. (2012), "Income Inequality in the European Union”, OECD Economics Department Working Papers, No. 952.

Cahuc, P. (2011), “Swedish Employment Protection Legislation”, in SOU 2011:11 Statens offentliga utredningar.

Dahlberg, M., K. Edmark, J. Hansen and E. Mörk (2009), "Fattigdom i Folkhemmet”, IFAU Report, No. 4.

De Dominicis, L., H. De Groot and R. Florax (2008), "A Meta-Analysis on the Relationship between Income Inequality and Economic Growth", Scottish Journal of Political Economy, Vol. 55, Issue 5. 
Duvander, A.-Z. and M. Johansson (2012), "What Are the Effects of Reforms Promoting Fathers' Parental Leave Use?", Journal of European Social Policy, No. 3.

Edmark, E., C.-Y. Liang, E. Mörk and H. Selin (2012), "Evaluation of the Swedish Earned Income Tax Credit", IFAU Working Papers, No. 2012:1.

Evertsson, M. and A.-Z. Duvander (2010), "Parental Leave - Possibility or Trap? Does Family Leave Length Affect Swedish Women's Labour Market Opportunities?", European Sociological Review, No. 4.

European Industrial Relations Observatory (2012), "Proposed Job Pact to Tackle Youth Unemployment", http://www.eurofound.europa.eu/eiro/2012/08/articles/se1208019i.htm.

Forslund, A. and O. Nordström Skans (2006), "Swedish Youth Labour Market Policies Revisited", Vierteljahrshefte zur Wirtschaftsforschung, Vol. 75, No. 3.

Forslund, A., P. Fredriksson and J. Vikström (2011), "What Active Labor Market Policy Works in a Recession?", Nordic Economic Policy Review, No. 1.

Fournier, J. and I. Koske (2012), "Less Income Inequality and More Growth - Are they Compatible? Part 7. The Drivers of Labour Earnings Inequality - An Analysis Based on Conditional and Unconditional Quantile Regressions", OECD Economics Department Working Papers, No. 930.

Glenngård, A., A. Anell and A. Beckman (2011), "Choice of Primary Care Provider: Results from a Population Survey in Three Swedish Counties", Health Policies, Vol. 103, Issue 1.

Government Offices of Sweden (2012), Sweden's National Reform Programme 2012, Stockholm.

Hakim, C. (2000), Work-Lifestyle Choices in the $21^{\text {st }}$ Century: Preference Theory, Oxford University Press.

Halldén, K. (2009), "Is it More Difficult for Women to Reach High Labour Market Positions in Countries with Gender Egalitarian State Policies?", Swedish Institute for Social Research Working Papers.

Heer, B. and A. Morgenstern (2005), “The Labour Market Effects of Indexing Unemployment Benefits to Previous Earnings", Public Finance Review, Vol. 33, No. 3.

Hoeller, P., I. Joumard, M. Pisu and D. Bloch (2012), "Less Income Inequality and More Growth - Are They Compatible? Part 1. Mapping Income Inequality Across the OECD", OECD Economics Department Working Papers, No. 924.

Immervoll, H. and M. Pearson (2009), “A Good Time for Making Work Pay? Taking Stock of In-Work Benefits and Related Measures across the OECD", OECD Social, Employment and Migration Working Papers, No. 81.

Joumard, I., P. Hoeller, C. André and C. Nicq (2010), Health Care Systems: Efficiency and Policy Settings, OECD Publishing, Paris.

Kierzenkowski, R. and I. Koske (2012), "Less Income Inequality and More Growth - Are They Compatible? Part 8. The Drivers of Labour Income Inequality - A Literature Review", OECD Economics Department Working Papers, No. 931.

Kjellberg, A. (2009), "The Swedish Ghent System and Trade Unions Under Pressure”, European Review of Labour and Research, Vol. 15, No. 3-4.

Kuczera, M., S. Field, N. Hoffman and S. Wolter (2008), A Learning for Jobs Review of Sweden 2008, OECD Paris.

Kumlin, J. (2007), "Disentangling Sex Segregation: Studies of the Roots and Routes of Labour Market Sex Segregation”, Swedish Institute for Social Research Dissertation Series, No. 70. 
Laun, L. (2012), “The Effect of Age-Targeted Tax Credits on Retirement Behavior", IFAU Working Papers, No. 2012:18.

Liljeberg, L., A. Sjögren and J. Vikström (2012), “Do New Start Jobs Lead to Higher Employment?”, IFAU Reports, No. 6 (in Swedish).

Magnusson, C. (2010), "Mind the Gap: Essays on Explanations of Gender Wage Inequality", Swedish Institute for Social Research Dissertation Series, No. 78.

Mandel, H. and M. Semyonov (2005), "Family Policies, Wage Structures, and Gender Gaps: Source of Earnings Inequality in 20 Countries", American Sociological Review, No. 70.

National Board of Health and Welfare (2001), Hälso- och sjukvårdsrapport 2001, Stockholm.

National Board of Health and Welfare (2007), Hälso- och sjukvård. Lägesrapport 2006-Primärvård, Stockholm.

National Board of Health and Welfare (2008a), Quality and Efficiency in Swedish Health Care: Regional Comparisons, Stockholm.

National Board of Health and Welfare (2008b), Hälso- och sjukvård. Lägesrapport 2007- hälso- och sjukvård, Stockholm.

Nolan, B. and C. T. Whelan (2010), "Using Non-Monetary Deprivation Indicators to Analyse Poverty and Social Exclusion: Lessons from Europe?", Journal of Policy Analysis and Management, Vol. 29, No. 2.

OECD (2005), OECD Economic Surveys: Sweden, Paris.

OECD (2006), Employment Outlook, Paris.

OECD (2008), OECD Economic Surveys: Sweden, Paris.

OECD (2010a), Off to a Good Start? Jobs for Youth, Paris.

OECD (2010b), Sickness, Disability and Work: Breaking the Barriers - A Synthesis of Findings across OECD Countries, Paris.

OECD (2010c), PISA 2009 Results: What Students Know and Can Do, Vol. I, Paris.

OECD (2010d), Learning for Jobs, Paris.

OECD (2011a), Divided We Stand: Why Inequality Keeps Rising, Paris.

OECD (2011b), Recruiting Immigrant Workers: Sweden, Paris.

OECD (2011c), Sick on the Job? Myths and Realities about Mental Health and Work, Paris.

OECD (2011d), OECD Economic Surveys: Sweden, Paris.

OECD (2011e), Health at a Glance 2011, Paris.

OECD (2011f), Report on the Gender Initiative: Gender Equality in Education, Employment and Entrepreneurship, Paris.

OECD (2012a), OECD Economic Surveys: Sweden, Paris.

OECD (2012b), Education at a Glance 2012, Paris.

OECD (2012c), Gender Equality in Education, Employment and Entrepreneurship, Final Report to the $M C M$, Paris.

OECD (2012d), OECD Thematic Follow-up Review of Policies to Improve Labour Market Prospects for Older Workers, Paris. 
OECD (2012e), Employment Outlook, Paris.

OECD (2012f), "Reducing Income Inequality While Boosting Economic Growth: Can It Be Done?", Going for Growth, Paris.

OECD (2012g), Mental Health and Work: Sweden, Paris, forthcoming.

Sabel, C. (2012), "Individualised Service Provision and the New Welfare State: Are There Lessons from Northern Europe for Developing Countries?", in OECD/The World Bank (2012), Promoting Inclusive Growth: Challenges and Policies, OECD.

Skedinger, P. (2006), "Minimum Wages and Employment in Swedish Hotels and Restaurants", Labour Economics, Vol. 13, No. 2.

Skedinger, P. (2010), Employment Protection Legislation: Evolution, Effects, Winners and Losers, Edward Elgar Publishing.

SOU (2010), "Vägen till arbete: Arbetsmarknadspolitik, utbildning och arbetsmarknadsintegration", Statens offentliga utredningar, No. 2010:88.

Statistics Sweden (2008), Women and Men in Sweden, Stockholm.

Swedish Fiscal Policy Council (2011), Report of the Swedish Fiscal Policy Council, Stockholm.

Swedish Ministry of Finance (2012a), How Should the Functioning of the Labour Market Be Assessed?, Report from the Economic Affairs Department at the Ministry of Finance, Stockholm.

Swedish Ministry of Finance (2012b), Evaluation of the Earned Income Tax Credit, Appendix 5 to the Spring 2012 Budget Bill, Stockholm.

Swedish National Agency for Education (2012), Upper Secondary Apprenticeship- The First Three Years 2008-11, Report No. 373, Stockholm (in Swedish).

van Doorslaer, E., C. Masseria and X. Koolman (2006), "Inequalities in Access to Medical Care by Income in Developed Countries", Canadian Medical Association Journal, Vol. 172, No. 2.

Venn, D. (2012), "Eligibility Criteria for Unemployment Benefits: Quantitative Indicators for OECD and EU Countries", OECD Social, Employment and Migration Working Papers, No. 131.

Visser, J. (2011), "Data Base on Institutional Characteristics of Trade Unions, Wage Setting, State Intervention and Social Pacts", 1960-2010(ICTWSS), Version 3.0, May, www.uva-aias.net/208.

Waldenström, D. (2009), Lifting All Boats? The Evolution of Income and Wealth Inequality over the Path of Development, Lund Studies in Economic History 51, Lund.

Wallette, M. (2005), “Temporary Jobs and On-the-Job Training in Sweden - A Negative Nexus?”, Lund University Department of Economics Working Papers, No. 13. 


\section{ANNEX 1 \\ LABOUR MARKET AND EDUCATION MEASURES RECENTLY PROPOSED BY THE GOVERNMENT}

The main structural reforms to combat long-term unemployment were launched in 2006 with the introduction of a compulsory guarantee programme for long-term unemployed, starting after the individual had been unemployed for 300 days (OECD, 2011d). Most unemployed were not supposed to benefit from specific programmes before this period. In parallel, a new subsidised job scheme was introduced ("New Start Jobs") and unemployment insurance was reformed to strengthen incentives to take a job. At the beginning of 2012, a statistical profiling tool was introduced to identify the unemployed most at risk of becoming long-term unemployed.

This Annex lists the main (labour market, education and social) measures proposed recently by the government to improve labour market outcomes, as part of the Budget Bill for 2013 or of other initiatives.

\section{Long-term unemployed}

- Provision of ALMPs from the first day of unemployment for the unemployed most at risk.

- Increase in subsidies for some subsidised jobs and training places for individuals in the third phase of the guarantee.

\section{Unemployment insurance and other social benefits}

- Increase in the number of sanctions for not complying with obligations but decrease in their severity.

- Unemployed will have to provide evidence of their job-search activities. An "activity report" is introduced for this purpose.

- Measures will be prepared to harmonise rules and requirements within different benefit systems, such as unemployment insurance, activity support and social assistance, and to improve information exchange between the PES and the municipalities.

- Clarification of the requirements that apply to all recipients of labour market-related benefits or other types of income support.

- Change in the calculation of social assistance to increase incentives to take a job.

Youth

- The subsidy to employers under the apprenticeship programme is doubled.

- More places in special schools (folk high-school) for those who did not complete upper secondary education.

- The increase in the study grant is extended. Increased funding for VET, including to increase the number of vocational teachers and to improve career guidance in school. Increased funding and responsibilities for the National Agency for Education in the area of VET. More places in the regular education system, with a special focus on VET. Launch of an investigation on the performance of the current VET system and how to improve it. 
- Increase in the subsidy under the New Start Jobs for youth unemployed more than a year.

- Increased support to the PES to address youth unemployment.

- Appointment of an inquiry (to report in August 2013) on how to reduce the share of youth in the NEET group.

\section{Immigrants}

- Introduction of a "practical year" for immigrants above 30 with a maximum of nine years of schooling including on-the-job-training, vocational Swedish language studies and theoretical education.

- Enlargement of the group that can benefit from the "Introduction Act". Increased requirements to accept a job offer for those under this programme.

- Extension of the subsidy under the "Step-In Jobs" targeting recently arrived immigrants.

\section{Talks with social partners}

With the social partners, the government is discussing how to improve the functioning of the labour market. The talks concern:

- Short-time working schemes. In some parts of the industry, short-time working schemes were introduced during the crisis in 2008-09. The government is looking at how to support these schemes in exceptional downturns.

- Youth unemployment ("Job Pact"). In some sectors the social partners have agreed on contracts that include $75 \%$ of the time on the job and $25 \%$ of the time in education with compensation equal to $75 \%$ of the minimum wage. The government has indicated its willingness to support these types of contracts.

- Transition in the labour market. The social partners have started negotiations on a wide range of topics, including EPL and adult education. 
$\mathrm{ECO} / \mathrm{WKP}(2013) 15$

\section{WORKING PAPERS}

The full series of Economics Department Working Papers can be consulted at www.oecd.org/eco/workingpapers/

1022. Educational attainment and labour market outcomes in South Africa, 1994-2010

(January 2013) by Nicola Branson and Murray Leibbrandt

1021. Education quality and labour market outcomes in South Africa

(January 2013) by Nicola Branson and Murray Leibbrandt

1020. Do policies that reduce unemployment raise its volatility? Evidence from OECD countries (January 2013) by Alain de Serres and Fabrice Murtin

1019. Slovakia: A catching up euro area member in and out of the crisis (January 2013) by Jarko Fidrmuc, Caroline Klein, Robert Price and Andreas Wörgötter

1018. Improving the fiscal framework to enhance growth in an era of fiscal consolidation in Slovakia (January 2013) by Caroline Klein, Robert Price and Andreas Wörgötter

1017. Investing efficiently in education and active labour market policies in Slovakia (January 2013) by Caroline Klein

1016. The performance of road transport infrastructure and its links to policies (January 2013) by Henrik Braconier, Mauro Pisu and Debra Bloch

1015. The US labour market recovery following the great recession (January 2013) by Wendy Dunn

1014. Why do Russian firms use fixed-term and agency work contracts? (December 2012) by Larisa Smirnykh and Andreas Wörgötter

1013. The Equity implications of fiscal consolidation (December 2012) by Lukasz Rawdanowicz, Eckhard Wurzel and Ane Kathrine Christensen

1012. The Dutch labour market: preparing for the future (December 2012) by Mathijs Gerritsen and Jens Høj

1011. Reforming policies for the business sector to harvest the benefits of globalisation in the Netherlands

(December 2012) by Mathijs Gerritsen and Jens Høj

1010. Health care reform and long-term care in the Netherlands (December 2012) by Erik Schut, Stéphane Sorbe and Jens Høj

1009. Enhancing the inclusiveness of the labour market in Belgium (December 2012) by Jens Høj

1008. Reducing poverty in Estonia through activation and better targeting (December 2012) by Sarah Flèche and Artur Radziwill 
1007. Matching skills and jobs in Estonia

(December 2012) by Lilas Demmou

1006. Debt and macroeconomic stability: An overview of the literature and some empirics (December 2012) by Douglas Sutherland and Peter Hoeller

1005. Debt and macroeconomic stability: Debt and the business cycle (December 2012) by Volker Ziemann

1004. Debt and macroeconomic stability: Case studies

(December 2012) by Rossana Merola

1003. Debt and macroeconomic stability

(December 2012) by Douglas Sutherland, Peter Hoeller, Rossana Merola and Volker Ziemann

1002. Reducing greenhouse gas emissions in a cost effective way in Switzerland.

(December 2012) by Anita Wölfl and Patrizio Sicari

1001. Strengthening innovation in the United States

(November 2012) by David Carey, Christopher Hill and Brian Kahin

1000. Long-term growth scenarios

(January 2013) by Åsa Johansson, Yvan Guillemette, Fabrice Murtin, David Turner,

Giuseppe Nicoletti, Christine de la Maisonneuve, Philip Bagnoli, Guillaume Bousquet and

Francesca Spinelli

999. Selected aspects of household savings in Germany - evidence from micro-data

(November 2012) by Christina Kolerus, Isabell Koske and Felix Hüfner

998. Improving the tax system in Indonesia

(November 2012) by Jens Arnold

997. Unleashing business innovation in Canada

(November 2012) by Alexandra Bibbee

996. Public policy and resource allocation: evidence from firms in OECD countries

(October 2012) by Dan Andrews and Federico Cingano

995. Promoting SME development in Indonesia

(October 2012) by Annabelle Mourougane

994. Portugal: Rebalancing the economy and returning to growth through job creation and better capital allocation.

(October 2012) by Álvaro Pina and Ildeberta Abreu

993. Public debt, economic growth and nonlinear effects: Myth or reality?

(October 2012) by Balázs Égert

992. Choosing the pace of fiscal consolidation

(September 2012) by Lukasz Rawdanowicz 